\title{
All in the Same Boat? Differences in Employment Experience and Risks During the First Wave of the COVID-19 Pandemic in Croatia ${ }^{1}$
}

\author{
Teo Matković \\ Institute for Social Research in Zagreb, Croatia \\ e-mail: teo.matkovic@idi.hr
}

\author{
Marko Lucić \\ Ministry of Labour, Pension System, Family and Social Policy, Zagreb, Croatia \\ e-mail:marko.lucic@mrosp.hr
}

\begin{abstract}
Experience of work amidst the first wave of the COVID-19 pandemic was subject to disruptions for most of the employed. According to results of the initial wave of a panel survey research (SOCRES project) conducted between August 20 and October 2 2020, analysed in this paper, six out of seven employed in Croatia encountered some of the observed workplace-related events (furlough, reduced workload, receiving state wage subsidies, working from home, disrupted work-life balance, wage reduction). We grouped the employed respondents into six segments considering epidemiological restrictions and support measures directly affecting the labour market. We examined differences in the incidence of disruptive events, in particular the disrupted work-life balance and reduction in wage and household income. We also examined differences in the perception of situation, contact with the virus, and selfreported health deterioration. Sociodemographic traits (education level, household type and composition, age, gender) and the role of wage subsidies were accounted for in explaining the variation in outcomes. Few inequalities between employment segments were found beyond those obviously arising from interventions. We found adverse effects of disruptive workplace events on earnings, perception of the situation and self-reported health deterioration. A drop in earnings occurred most often among the self-employed and disrupted work-life balance among educators and healthcare workers. Broad state support via wage subsidy amounting close to minimum wage reassured workers, yet was insufficient to compensate. The necessity of robust and effective lockdown-proof public education and care services came to fore during the initial wave of the pandemic, as all the workers had to engage in providing those within the family, leading to increasing work-life balance challenges.
\end{abstract}

Key words: COVID-19, Croatia, workers, labour market inequalities, workplace-related events, earnings, work-life balance, health.

1 Ovaj rad nastao je u sklopu projekta Otpornost hrvatskog drustva uslijed COVID-19 pandemije (IP-CORONA-04-2044) financiranog od strane Hrvatske zaklade za znanost (HRZZ-CORONA).

Copyright (c) 2021 Institut za društvena istraživanja u Zagrebu - Institute for Social Research in Zagreb Sva prava pridržana - All rights reserved 


\section{Introduction}

Croatia seems to have staved off major disruptions in labour market activity and mass unemployment in the face of the first wave of the COVID-19 pandemic in spring 2020. The administrative number of persons in employment actually increased from 1,515 to 1,529 thousand $(+0.9 \%)$ between February and September. While this tourism-induced seasonal increase was much weaker than 2009-2019 average (+3.6\%) (Državni zavod za statistiku 2021, tables 9.2.1-9.2.3), there was no collapse in the number of persons in employment, as the annual change in registered employment in September 2020 amounted to -2.0\% (cf. 1,561 in Sep 2019), while Labour Force Survey data indicated $1.6 \%$ annual drop in employment in the third quarter of 2020 $(1,704 \text { to } 1,678)^{2}$.

Yet many of those that held onto their jobs faced change in the circumstances of their employment, inducing changes in work patterns, space or remuneration, as well as introducing new challenges to work-life balance and health risks. In this paper, we strive to identify the extent of such changes in general, and whether some groups of workers were affected to a greater extent. We will try to understand those in the context of policy interventions and regulations that were introduced during the first wave of the pandemic in spring 2020.

The article proceeds as follows. First we are set to provide a systematic overview of the findings from the 2020 wave of international research that address work-related effects of the pandemic in middle and high income countries and to identify the main dimensions of inquiry. Then we portray the timeline of pandemic-related policy interventions and restrictions in Croatia, which have directly affected the employment experience for some or all persons in employment. Based on this, we develop a categorization of workers and an analytic strategy. Based on the first "Social resilience of Croatian society in the midst and aftermath of the COVID-19 pandemic" (SOCRES) survey, we assess the incidence of home-based telework, furlough period, reduction in workload, reduction of wages and household income, and deterioration of work-family balance during the initial wave of the COVID-19 pandemic. We also assess which employment segments are most likely to have been affected by each of work-related events, the role of demographics and the effect of state subsidies. The analysis continues with an exploration of the variation in earning loss and the percep-

\footnotetext{
2 This was enough to make for a remarkable growth of the unemployment pool. The year-on-year increase in September 2020 stood at 35.1 thousand $(+31.2 \%)$, a noted deterioration from February, when unemployment was 18.4 thousand persons (11.7\%) lower than February 2019 (Hrvatski zavod za zapošljavanje, 2021). Furthermore, unemployment entries from employment increased by $27.5 \%$ over the period, mostly in March (51\%) and April (110\%), while vacancies decreased by $35 \%$. While the unemployed count in Croatia is still lower than it was in any year over the entire 1991-2017 period, the hardships the pandemic inflicted upon the unemployed is certainly worth further exploration.
} 
tion of current situation, as it relates to work-related changes and subsidies. Finally, we consider employment-related differences in contact with the pandemic or health deterioration among the employed.

\section{Work-related events during the pandemic}

Ample literature based on research about work-related changes induced by the COVID-19 pandemic started emerging as early as spring 2020. The most commonly observed change among the employed was related to reduction in hours worked, all the way up to being furloughed and not being present at the workplace at all. Such arrangements were in most cases supported (e.g. European Commission, 2020; OECD, 2020) via government short-time work, furlough, or employer subsidy schemes. An early Eurofound effort to track living and working in the context of COVID-19 (in April and July) based upon e-survey filled in by self-selected respondents has identified almost half workers (49\%) working fewer hours than prior to the pandemic in April, down to $37 \%$ in July. With respect to sectors, decrease in hours worked was least prevalent in public administration and health (21\%), education ranking about average $(36 \%)$, whereas in industry, transport, construction, commerce and hospitality about half respondents reported decreased hours (Eurofound, 2020: 11). A three-country study (USA, UK, Germany) identified similar sectoral patterns, with respectively $31 \%, 43 \%$ and $35 \%$ of employed being furloughed or in short-time work (Adams-Prassl et al, 2020, UK panel reports 26\% furloughed in April per Crossley et al, 2021), with average change in working hours being 5, 7 and 4 hours respectively. In Canada average reduction of workweek was 1.6 hours in the initial phase of lockdown, with decline greater among the younger and less educated (Beland et al, 2020). In Germany and the Netherlands, short-time work and working time reduction was persistently more prevalent among low-income groups and workers without tertiary education (Schröder et al, 2020; Möhring et al, 2020a; Von Gaudecker et al, 2020).

Second, income might have been affected even for workers retaining their jobs, either due to other household members losing their jobs, reduction in working hours, wage cuts, or low replacement rate of compensatory measures. The recent EU employment income nowcasting effort by Eurostat (2020), using EUROMOD simulation model and Labour Force Survey (LFS) data, casts 2020 employment income loss at EU level at $4.8 \%$, but with a large variation between countries, and Croatia at the high end $(10.6 \%)$. Most of the income loss emerges from absences from work, and working reduced hours, with transitions to unemployment playing a minor role (in particular in Croatia). There is a strong sectoral dimension in income loss, most prominently a decrease evident in food and accommodation (I) and arts (R) sectors, with construction and sales (F, G) having above-average decline as well. The relative income loss is in all countries modelled to be higher for youth and low-income groups, but in Croatia differences are modest (about 13.5\% for low-income, 10.3 for mid-income and 
9.9\% for high-income group). In a three-country study including USA, UK and Germany, $35 \%, 30 \%$, and $20 \%$ workers, respectively, reported decline in earnings, with a chance of reporting earning loss consistently lower among salaried employees and those having fixed hours contracts (Adams-Prassl et al, 2020), and when tasks could be done from home (except for Germany). More frequent or intensive income loss for the younger, low-waged, and for workers in marginal employment was a common finding in most studies that addressed the issue (Beland et al, 2020 for Canada; Holst et al for Germany, Crossley et al, 2021 for UK). Income loss might in particular incur other hardships, a linkage confirmed in this case by findings of a Swiss household panel study, suggesting that change in financial situation during the initial wave of the pandemic triggered both increased stress and life (dis)satisfaction (Kuhn et al, 2020).

Third, the pandemic has caused a major shift towards working from home, or telework. Eurofound EU-wide study identified nearly half respondents worked from home during the pandemic at least some of the time (33.7\% employees home only, $14.2 \%$ mixed). Those were more likely to be tertiary educated and from managerial and professional occupations, living in cities/suburbs, working in education and public administration, financial or other services. On the other hand, less than a quarter of those employed in transport, health, commerce and hospitality worked from home at all (Eurofound, 2020: 32-33, Sostero et al, 2020: 21-26; Belot et al 2020:10; Von Gaudecker et al, 2020). Persons in higher income groups and with higher education were consistently identified to be more likely to telework in Germany (Möhring et al, 2020a; Schröder et al, 2020) and the Netherlands (Von Gaudecker et al, 2020). Being able to engage in telework practices and substitute on-site hours during the pandemic has been consistently shown to moderate adverse effects, such as reduced working hours (e.g. 28\% among teleworkers vs 38\% among others in Eurofound study), or assessed risk of losing one's job (Beland et al, 2020). Further on, having a large share of tasks that can be done from home was associated with job retention during the onset of the pandemic (Adams-Prassl et al., 2020). Yet many "emergency teleworkers" assess their productivity to be lower (41\% per Schröder et al, 2020).

Many occupations and workplaces include physical tasks or tools that technically cannot be implemented remotely, whereas jobs strongly relying on social interaction might experience limited usefulness of such work. Several authors have constructed teleworkability indices based on job characteristics sourced from USA O*net (Beland et al, 2020) or Italian Survey of Professions (ICP) and European Working Conditions Survey (Sostero et al, 2020), thus estimating the ceiling of current workforce able to engage in telework (e.g. 37\% in EU-27, 34\% in Croatia according to Sostero et al, 2020). They have identified a strong association of potential and actual switch to remote work during the pandemic, with such jobs being concentrated in managerial, professional and clerical occupations, and most high-contact, physical-manipulation, low-skill and low-income jobs not being teleworkable. 
Fourth, changes and challenges in the work-life balance were often examined, as much of the care and education infrastructure shut down during the initial lockdown period. According to Eurofound study, the challenges were greater among parents of children under 12 years of age, in particular mothers and those engaged in telework (Eurofound, 2020: 22). Among those working at least some time from home, and controlling for individual and job characteristics, women in the USA, UK and Germany still on average spent 1.1-1.4 hours more than men on active childcare or home schooling (Adams-Prassl et al, 2020). In Germany, the division of child care and housework seem to have moved into a more egalitarian direction during the early lockdown, division of care corresponded to the partner that worked from home, but bounced back towards the baseline over time. Both work and life satisfaction suffered during the lockdown, in particular among the parents (Hipp \& Bünning, 2020; Kuhn et al, 2020 found stress to decrease though). Möhring et al (2020b) using panel data identified no change in work or family satisfaction while switching to work from home, and decline in work satisfaction (yet increased family satisfaction) with transition to short time work, in particular among mothers. A paper based on COVID-19 extension of German National Educational Panel Study (Zoch et al, 2020) ventured to identify care arrangements in families with school-aged children during the pandemic, and their association with the working arrangement. While no specific patterns emerged for key workers, both mothers and fathers working remotely were more likely to take up caring arrangements, albeit having working hours reduced was associated with maternal care for mothers only. Nevertheless, in the UK Crossley et al identified that $7 \%$ of men and $8 \%$ of women reported reducing working hours during the pandemic due to care responsibilities (Crossley et al, 2020).

Fifth, there are differences in exposure to health risks for various professions. In Eurofound study (2020:42), self-assessed risk of contracting COVID-19 due to their job was found to be highest in health sector, followed by commerce, hospitality and transport sector, then education. Indeed, the perceived risk of contracting was higher among those whose jobs always or most of the time include direct physical contact with people. Similar estimates were collected by Belot et al. (2020:12), with belief of having been infected with COVID-19 most common in health workers, then among retail and other services, closely followed by education. Consistently, the application of Oesch class scheme in the German context by Holst et al. (2020) established that workers from interpersonal and technical classes, as well as those on fixed-term contracts were more likely to report at-work infection risk.

Several studies have used $\mathrm{O}^{*} \mathrm{Net}$ job characteristics (exposure to disease and infection, close interactions at work, number of contacts), identifying higher occupational risk of coming down with COVID among health, education and retail workers (Beland et al, 2020, Belot et al, 2020, St-Denis, 2020, Lu, 2020). The same source was used to predict, minuscule differences in risks in terms of occupational sociodemographics (slightly lower for men, highly educated, older employees), but higher physical prox- 
imity risk for low-income occupations (St-Denis, 2020). Indeed, a pandemic-timed increase in absences was identified in occupations characterized by working in close proximity to coworkers or with greater exposure to infections (Beland et al, 2020).

There are some studies reporting occupational differences in actual health outcomes during the COVID-19 pandemic. By tracking changes in reported sickness-related absences, a survey of USA current population during the outset of the pandemic, Lyttelton and Zang (2020) have identified largest increases among transportation and food-related occupations, and increases in personal care and service occupations, with low incidence among better-paid and higher-educated professional and managerial occupations. Occupations likely to practice remote work, flexible hours, and health insurance were associated with lower increase in sick leaves, whereas physical proximity increased the risk (but working with customers or indoors did not). Occupational traits account for the majority of the observed differences in sick-leaves with respect to education, income or race. As for the actual COVID-19 occupational mortality, a report based on the registered UK fatalities up to May 25 (Office for National Statistics UK, 2020) singled out elementary occupations as having the highest COVID-19 death rates, in particular security guards. Other high-risk occupations included care workers and home carers, nurses, sales and retail assistants, drivers (taxi, bus, van) and chefs.

In general, regardless of the subject explored and countries involved, most analyses indicate less adverse outcomes for workers with higher education, more income and in professional/managerial position, as well as those in stable working arrangements. Following the Oesch class paradigm, Holst et al. (2020) frame this as horizontal differentiation and vertical stratification of economic and health risks during the COVID-19 pandemic.

There were few cross-cutting findings regarding the divergence in outcomes regarding age or gender. As for the gross effect of the first phase of the pandemic on working women, apart from the impact on work-life balance, no major gender differences in working hours or telework were identified in Eurofound study (2020). More broadly, in a three-country study extending outside Europe, employed women were identified as more likely than men to transition to work from home and reduce working hours in USA, but not in Germany or Singapore (Reichelt, Makovi and Sargsyan, 2020).

Public-private employment divide was seldom explicated, but in Swiss household panel study no differences in change with respect to stress or satisfaction were identified among public sector employees compared to private (Kuhn et al, 2020). However, most studies did find the self-employed (both without and with employees) as a group that was heavily affected, being most likely to face decrease in working hours, income and security during the COVID-19 pandemic (Eurofund, 2020:45-47; Holst et al, 2020; Adams-Prassl et al. 2020; Crossley et al., 2021; Von Gaudecker et al, 2020; Beland et al 2020). 


\section{Policy response to the pandemic relevant to the labour market}

The labour market disruption emerged from both the pandemic spread and the measures taken to tackle it. In order to understand who might have been more affected, and in which fashion, we will portray pertinent governmental restrictions as they were introduced and relaxed, as well as the relief measures introduced. In this overview, we will remain focused only on the interventions that have directly affected work for some or all workers.

\subsection{Restrictions}

Government-imposed restrictions emerged in Croatia in mid-March in quick succession, closely following most other EU countries. Indicative of that, the Oxford COVID-19 Government Response Tracker stringency index (Hale et al, 2020) increased from 22 to 96 between March 12 and March 23, then remained at such a high level until mid-May. Yet, going into more detail with respect to work-related restrictions and interventions is essential to framing and understanding how the crisis might have affected various segments of workforce.

Much economic activity was shut down on March 19, including non-essential shops, all hospitality, personal services, taught courses and recreation activities, with all employers urged to organize work from home. The escalation ended with the closure of marketplaces and restriction of working hours for essential shops on March 22. The relaxation was gradual, starting with regulated reopening of covered markets (March 28) and open-air markets (April 8), reopening of non-essential shops and reintroduction of regular working time (April 24). Personal services were allowed on May 11. Most of remaining operating restrictions were lifted on May 18 (including cultural events and working Sunday). However, the regulation Article mandating employers to organize work from home where possible has remained, as have distancing and hygiene guidelines for clients and workers at the employer premises.

As for measures affecting mobility, major impediment to mobility appeared on March 22 via a comprehensive stoppage of local, regional and international public transport, immediately followed on March 23 by a ban on leaving the town/municipality of residence (except for the purpose of work, if working from home is not possible, medical, care and necessary supply). The permit regime was relaxed to county-level mobility on April 20 and all the internal mobility limits were lifted on May 11. In line with this relaxation, local public transport was reintroduced on April 24, with national lines being re-established from May 11.

As for the operation of the education system, which is the workplace of every thirteenth worker in Croatia and key to managing existing work-life arrangements for families with children, on March 16 all in-person classes (from kindergartens to uni- 
versities) were put on hold, and transitioned to virtual, online and TV-based modalities. After 10 weeks, on May 25 kindergartens and primary education (ages under 11) reopened, following the public health recommendations, whereas lower and upper secondary education remained online for further four weeks until the end of the school year (June 17).

The healthcare system was shuttered and resources mobilised for the forthcoming pandemic, with series of measures introduced over the period March 13-19. In this operation regime, admissions, diagnostics and treatments were temporarily limited to emergency cases, and primary healthcare and outpatient services were postponing most in-person appointments. Regular operations were resumed on May 4, albeit with triage procedures in force and an increase in waiting lists. Care homes were subject to additional strain as safety procedures were repeatedly reinforced since late February in order to control outbreaks, and for much of the lockdown period elderly residents had severely limited options to receive visits or leave.

\subsection{Support measures}

Most countries have introduced mechanisms of state support for workers and businesses affected by the pandemic. This in general included helping firms and sectors to manage via facilitating access to liquidity instruments and tax holidays, and measures directly affecting workers via instruments such as short-time work (eg. Germany, Denmark) or paid furlough schemes (e.g UK, Romania), subsidies for businesses in difficulties paid per worker (e.g. the Netherlands, Ireland, Estonia), or extended unemployment benefits (e.g. USA, Denmark). While those instruments are not mutually exclusive, most countries were focused on a single one (OECD, 2020), and Croatia opted for business subsidies per worker.

Policy measures aimed at preventing job loss due to introduced restrictions were announced on March 17 and introduced on March 20. With some procedural changes, those measures persisted until end-May. Subsidies were available sector-wide for businesses in food and accommodation, transport and storage and in "work-intensive" industries within the manufacturing section. Other employers could qualify for those subsidies if they had a year-on-year drop in revenue of at least 20 percent in respective months. Micro employers with up to 10 employees could also qualify with only a proof of cancelled business deals in the relevant period. Eligible businesses could get flat subsidies plus social contributions. Subsidies amounted to minimum wage $(3,250$ HRK) per full-time worker for March, raised to 4,000 HRK per full-time worker for April and May. In total, subsidies were provided for 503 thousand workers for March, 586 for April and 507 for May (Hrvatski zavod za zapošljavanje, 2020). After the restrictions on business activities have subsided, the criteria for subsidies were set more restrictively. In June, only those in selected industry sectors could qualify, 
provided that they also proved a drop in revenue of at least $50 \%$ in May, while in July and August the required revenue loss criteria was increased to $60 \%{ }^{3}$. Narrower criteria reflected on lower coverage of subsidies in the summer months, with 84,72 and 51 thousand workers, respectively. A short-time working scheme was introduced in June, limited to businesses employing more than 10 employees, but it had fewer beneficiaries: 8,11 and 10 thousand employees in the three summer months.

In a comparative context, Croatia had high coverage of the employed included in its wage subsidy scheme, topping at about 38\% in April. Unlike furlough schemes in the UK or short-time working schemes in Germany, no restrictions were set on the number of working hours or workplace presence for workers covered by subsidy. Thus, in Croatia there was no mandated reduction in working hours or periods of absence from workplace for workers covered by subsidies, the only requirement being continuation of the employment contract and full wage payment. Notably, no special measures were directed to the self-employed, as the same set of provisions for wage subsidies applied to the self-employed (both incorporated and unincorporated entities) as to other micro-employers. Yet, the coverage of the self-employed in Croatia was lower (around 22\% in April) than for the wage subsidy scheme in general.

\section{Data and analytic strategy}

In order to deepen our understanding on work during the initial wave of the COVID pandemic in Croatia, we use data from the initial survey effort of the project "The social resilience of Croatian society in the midst and aftermath of the COVID-19 pandemic" (SOCRES). The telephone-based survey was executed by the Valicon company between August 20 and October 2 2020, and reached a total of 1,512 adult respondents. This includes 1,212 respondents sampled from the population of households with listed land-line phones, and 300-respondent booster drawn from the pool of the Valicon "JaZnam" panel ${ }^{4}$. With respect to working life, this survey contained questions on employment status and occupation of respondents immediately prior to the pandemic and during the survey rollout, whether they changed job or have lost job due to the pandemic, and a set of items regarding work-related changes since the onset of the pandemic. This survey acted as the initial round of an ongoing panel design, and relied upon a retrospective recollection on the period from the onset of the pandemic until the time of the interview (that is, about previous 6-7 months). The data used in the analysis was weighted using RIM metod, accounting for region, settlement size, gender, age group and education level.

3 In July and August, micro-employers had again a more favourable treatment, with an option of receiving support of 2,000 HRK per worker even if not among the selected sectors, if their revenue drop was at least $50 \%$

${ }^{4}$ The response rate for the population sample stood at $4.8 \%$ (based on 25,393 contacts), and with the panel booster 36.5\% (based on 911 draws). 
For current analyses we focus on the sub-sample of 682 persons who have remained in the same employment throughout the first wave of the pandemic (from February to the interview date). ${ }^{5}$

Based on the international findings, and the described restrictions and support mechanisms enacted in the Croatian labour market, we have identified six categories of workers (employment segments), whose specifics in the structural position and context should have warranted differences in experience of work during the pandemic. First, the self-employed and small employers, who were often facing large drops in demand or restrictions in operation, while subsidies compensated basic labour costs only. The next three segments correspond to occupations specifically affected by the restrictions described above. Health and care workers (ISCO 22,32,53), as their work regime changed towards emergency readiness, and direct contact with the disease. Educators (ISCO 23), as they manage a large number of contacts and have completely switched to distance teaching. And sales, personal service and transport workers (ISCO 511-514, 52, 83,94), as their employment depends on personal contact and activities that were severely restricted during the lockdown. The remaining workers were categorized by ownership as public sector workers (who had the mandate to organize their work so to ensure the continuity of services, but were budgetary funded and not exposed to job loss risk - unless temporarily employed), and private sector workers (exposed to strong disruptions in demand, supported by flat-level benefits without conditions on hours worked).

With those groups of workers, we articulate our analytic strategy as follows. First, we will assess the prevalence of workplace-related events during the first wave of the pandemic and the differences between employment segments with respect to their incidence. We will explore if observed gross differences persist when controlling for workers' sociodemographic and whether engaging in home-based work, furlough periods and reduction in work activity are associated with receiving wage subsidies (as subsidies were not conditional on change in working patterns). Finally, we will explore the structure of the workforce with respect to their potential teleworkability.

Next, we will explore whether some categories of workers were more likely to face increased challenges in managing work-family balance, in particular whether those

5 The survey has identified 5.1\% of those employed in February not working in September, while 4.1\% of those employed in September were not working in February, making for $-1.1 \%$ net change in total employment (95\%CI -3.5\%-1.6\%) over the first wave, close to estimates achieved from administrative sources and LFS data. In particular, 3.7\% of those employed prior to the pandemic reported working in another job by the time of the survey, and $2.6 \%$ reported experiencing losing job due to the pandemic, about half of them in sales or personal services. Despite this standing for tens of thousands of workers, the low incidence of event in this general population sample does not allow for deeper quantitative exploration of pandemic-related unemployment and labour market flows within the SOCRES project. 
were gender-specific, associated with change in working patterns and presence of children or elderly in the household.

Third, we will explore differences in the incidence of reduction of earnings in terms of working income and negative change in household disposable income, and how those are related to the workplace-related events and wage subsidies.

Fourth, we will assess how all of the work-related events and interventions discussed above relate to perceived gravity of situation, a questionnaire item related to resilience, meant to tap into the general perception of how disruptive the circumstances are due to the pandemic, as opposed to "normal" circumstances.

The last dimension concerns the health aspect, as we assess employment-related differences in contact with COVID-19 and self-reported health deterioration among the employed.

Most dependent variables in inferential analyses are binary, whereby we used logistic regression. Among dependent variables, only household income reduction and perceived gravity of situation were applied as scales. Perceived gravity of situation was coded with values ranging from 0 to 5 with the baseline category ("completely normal situation, as before the pandemic") being coded as 0 , and the highest perceived disruption ("situation completely hopeless") being coded as 5. Household income reduction was coded with values ranging from -2 to 2 , where the centre value (0) was assigned to the response expressing no substantial change in household income. In the analyses of the latter two dependent variables we used linear regression.

To enhance the interpretability of regression results (effect sizes), we present all regression results using marginal effects calculated at means of other covariates. In case of binary outcomes (logistic regressions) and categorical independent variables (covariates), for each category of a covariate marginal effect is a percentage point difference in the outcome probability from the reference category of that covariate, calculated under the assumption that other covariates are at their means. In case of quantitative outcomes (linear regressions) marginal effect is a difference in the average predicted value of dependent variable holding other covariates at their means. Reporting marginal effects at means (MEMs) instead of reporting odds-ratios or log-odds provides a scale of effect sizes that is similar to the probability range in the case of binary outcomes, and it also provides results for an "average respondent", not for a person having all values of other covariates at reference categories, which might be a rare occurrence in reality and hence possibly misleading results' interpretation. Confidence intervals shown in figures pertain to marginal effects and do not necessarily correspond to confidence intervals of regression coefficients. In all the regression analyses, we used a set of controls including gender, age, education level and household type. Annex Table 
A1 shows sample frequencies and outcomes' incidence with respect to control variables and employment segments. Survey weights were applied in all analyses to ensure that descriptive statistics and effects shown account for the population composition by region, settlement size, gender, age group and education level.

\section{Results}

Our results indicate that all kinds of disruptions to established working patterns were commonplace during the initial wave of the COVID-19 pandemic. While none was ubiquitous (Figure 1), 86\% of workers reported at least one, on average 1.95 disruptions. Furlough periods and decreased workload were most common (with 36-38\% workers reporting), while reduction in wage was least frequently reported, by about a quarter of workers, with wage subsidies, work from home and increased work-family challenges being in between, reported by about a third of workers.

Notably, almost a fifth of all respondents could neither confirm nor deny that they were beneficiaries of wage subsidies. This is expected, as subsidies were not conditional on informing an employee or their consent, and were not visible in a wage receipt, so unlike for other items, many respondents could not provide a definite answer. Thus, the share of beneficiaries of subsidies presented here is likely underreported ${ }^{6}$.

Figure 1.

Share of workers employed throughout the pandemic who have experienced work-related events.

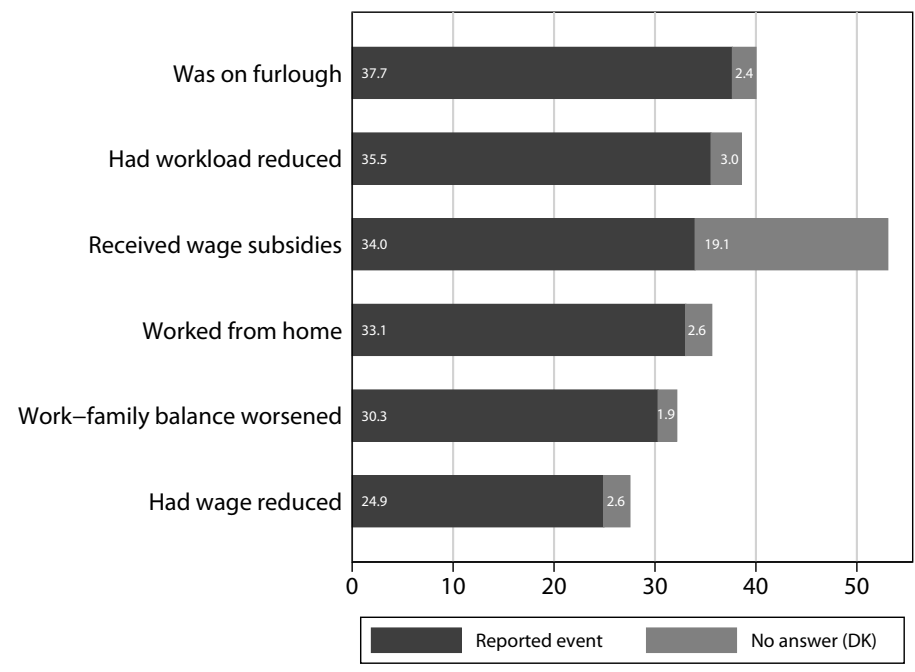

6 In order to account for this and retain the cases, we chose to treat "no answer" on subsidies as a separate answer category in the inferential analysis that follows. 


\subsection{Changes in working patterns and subsidies}

With respect to most aspects explored here, various employment segments demonstrated different patterns of change (Table 1). Working from home was almost ubiquitous in education and next to absent in sales and personal services. It was the other way around with respect to furlough periods, although differences were smaller. Wage subsidies were mostly concentrated in activities dominated by the private sector, as were reductions in wages, in line with eligibility criteria. Observed differences between workers in reduction of workload or work-family balance were less striking, with workers in education sector least likely to report workload reduction and most likely to report work-family disbalance.

Table 1.

Incidence of workplace-related events during the first wave of the pandemic by employment segments

\begin{tabular}{|l|c|c|c|c|c|c|}
\hline & $\mathbf{N}$ & $\begin{array}{c}\text { Worked } \\
\text { from home } \\
(\%)\end{array}$ & $\begin{array}{c}\text { Was on } \\
\text { furlough } \\
(\%)\end{array}$ & $\begin{array}{c}\text { Had } \\
\text { workload } \\
\text { reduced } \\
(\%)\end{array}$ & $\begin{array}{c}\text { Received } \\
\text { wage } \\
\text { subsidy } \\
(\%)\end{array}$ & $\begin{array}{c}\text { Work-fam- } \\
\text { ily balance } \\
\text { worsened } \\
(\%)\end{array}$ \\
\hline Total & 682 & 33.7 & 36.8 & 36.0 & 33.8 & 32.0 \\
\hline Health and care & 56 & 16.3 & 37.7 & 41.3 & 7.9 & 46.4 \\
\hline Education & 75 & 93.7 & 22.3 & 17.6 & 9.1 & 54.1 \\
\hline $\begin{array}{l}\text { Sales, personal ser- } \\
\text { vices and transport }\end{array}$ & 57 & 8.5 & 61.8 & 40.7 & 50.4 & 29.9 \\
\hline Self-employed & 67 & 52.6 & 45.1 & 49.6 & 43.9 & 38.4 \\
\hline $\begin{array}{l}\text { Public sector } \\
\text { (other) }\end{array}$ & 167 & 43.6 & 35.3 & 30.7 & 14.9 & 24.4 \\
\hline $\begin{array}{l}\text { Private sector } \\
\text { (other) }\end{array}$ & 260 & 26.2 & 31.3 & 36.0 & 45.0 & 29.4 \\
\hline
\end{tabular}

Note: " "No response" counted as not having received subsidy

Next, we introduce gender, age and level of education as controls for receiving wage subsidies, and work-related events that pertain to work organization (work from home, furlough, and decrease in workload) in models depicted in Figure 2. Demographics do not seem to account for major differences in most of these outcomes. Women were more likely to face decrease in workload (14 percentage points) and work at home (11 p.p.). Workers with less than tertiary education had a considerably smaller propensity of homeworking (for 45 to 58 p.p. smaller compared to workers with a university degree). Workers with technical or general secondary education tended to be covered by subsidies and to be put on furlough. Furlough was also more common for workers without upper secondary education. 
Notably, the effect of employment segments on work-related events remains a robust net of gender, age and education structure of employees within. Employees in occupations pertaining to shuttered businesses, self-employed and private sector in general had higher propensity to receive subsidies, which is in line with the eligibility criteria, while education and non-shuttered private sector employees were less likely to have experienced furlough compared to occupations undergoing closure. No significant differences with respect to having workload reduced emerged between employment segments. Differences between employment segments in having worked from home remain robust, with educators and self-employed being most likely, while health and care, as well as sales and personal service workers being least likely to have engaged in such an arrangement during the pandemic.

While wage subsidies were conditional on sectoral basis or revenue loss, there was no mandate to furlough or introduce short-time work. Yet, such practices were not prohibited either, so we have explored possible associations in the model. Other being the same, receiving subsidy was associated with higher propensity for entering furlough and experiencing reduction of workload, as well as with lower propensity to engage in work from home.

Figure 2 .

Work-related events with respect to employment segment, demographics and having received wage subsidy

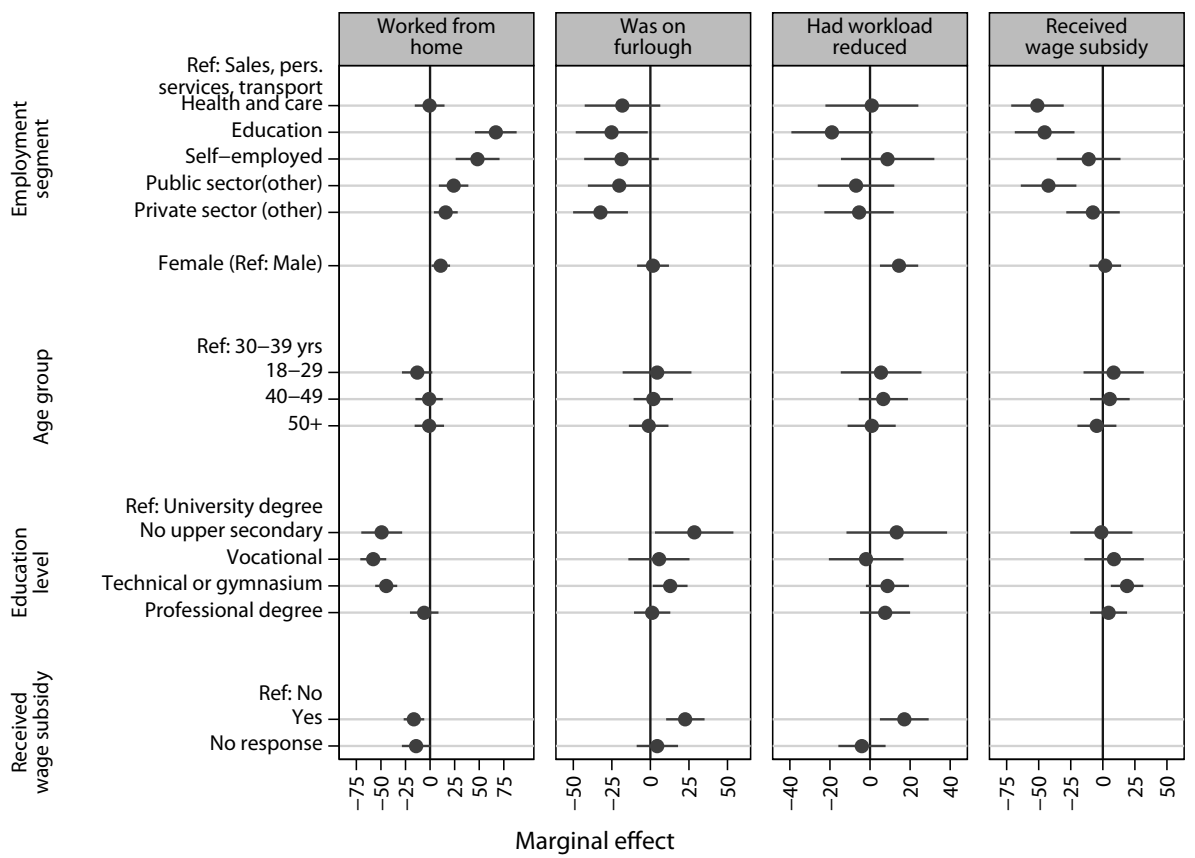

Note: Marginal effects in percentage points with their $95 \%$ confidence intervals, holding other covariates at means. Confidence intervals which do not cross the vertical line denote significant marginal effects. Underlying logistic regression shown in Table A2. 
In order to examine how much the potential for telework was realized during the first wave of the pandemic in Croatia, we have applied the framework developed by Sostero et al (2020: Table 3) to our dataset, coding occupations as teleworkable by their requirement for physical interaction and social interaction requirement. Similar to the Sostero et al (2020) study, we have identified $64.3 \%$ of workers being in jobs deemed not fit for telework (physical interaction index over 0.5), 29.0 worked in jobs where telework is feasible, but social interaction extensive, while only $6.7 \%$ worked in jobs technically teleworkable not requiring intensive social interaction. Very few workers from categories "Health and care" (3\%) and "Sales, personal services and transport" $(2 \%)$ worked in occupations fit for telework, while all the "Education sector" workers did, but with a high social interaction requirement. Other groups were close to the population average, with $63 \%$ self-employed, $64 \%$ other private sector and $50 \%$ of other public sector employment belonging to occupations that can hardly be practiced at home. Actual, reported telework practices during the pandemic were more likely to have happened in jobs characterized by high teleworkability, both with limited (58\% did telework) and extensive social interaction (73\% did telework), whereas it seldom happened in the majority of jobs deemed not teleworkable, as only $13 \%$ of those worked from home. We have crosstabulated actual telework and other changes in working patterns according to the teleworkability criteria and found working from home being concentrated in occupations where it is technically feasible.

\subsection{Work-life balance}

Switching our analytical focus to reported disruptions in work-life balance (Figure 3 below, Annex Table A3), we find a strong effect of household composition, with households containing children in compulsory education age (7-14) being more likely to face new challenges than others, as their children ceased to physically attend school ${ }^{7}$. The deterioration of work-life balance was as likely to be reported regardless of parental education level.

The observed differences between employment segments persisted, net of other household and personal characteristics or workplace events. Namely, health, care and education workers were much more likely to report worsening of work-life balance than were other employees in similar circumstances.

Notably, we found no evidence of deterioration in work-life balance being associated with reported reduction of income or with changes in work-place organization in our specification. However, it is possible that the specific working regime of health sector

${ }^{7}$ The effect is weaker and not significant for pre-school age children, most likely due to ECEC enrolment in Croatia being fairly low, so non-attending families were not disrupted by the closing of kindergartens. 
during the pandemic, as well as the specifics of ubiquitous distance teaching among education workers, coupled with the absence of effective family support (school and care) services for those groups, did manifest as a sectoral effect.

With respect to gender, in a single-variable model, women were more likely to report deterioration than men $(\log$ OR $0.41, \mathrm{z}=2.04, \mathrm{p}=0.042)$. However, this effect ceased once sectoral composition is accounted for, as both health and education sectors have a strongly feminised workforce. In order to check for gender-specific patterns or effects, we ran separate models for men and women. Remarkably, both identified similar marginal effects of covariates. However, there are some peculiarities reminiscent of traditional gender-roles, as reduction in workload was associated with deterioration in work-life balance for men only, whereas presence of children in lower-secondary education and elderly in the household was significant among female workers only.

\section{Figure 3.}

Deterioration of Work-family balance with respect to work-related events, employment segment and demographics
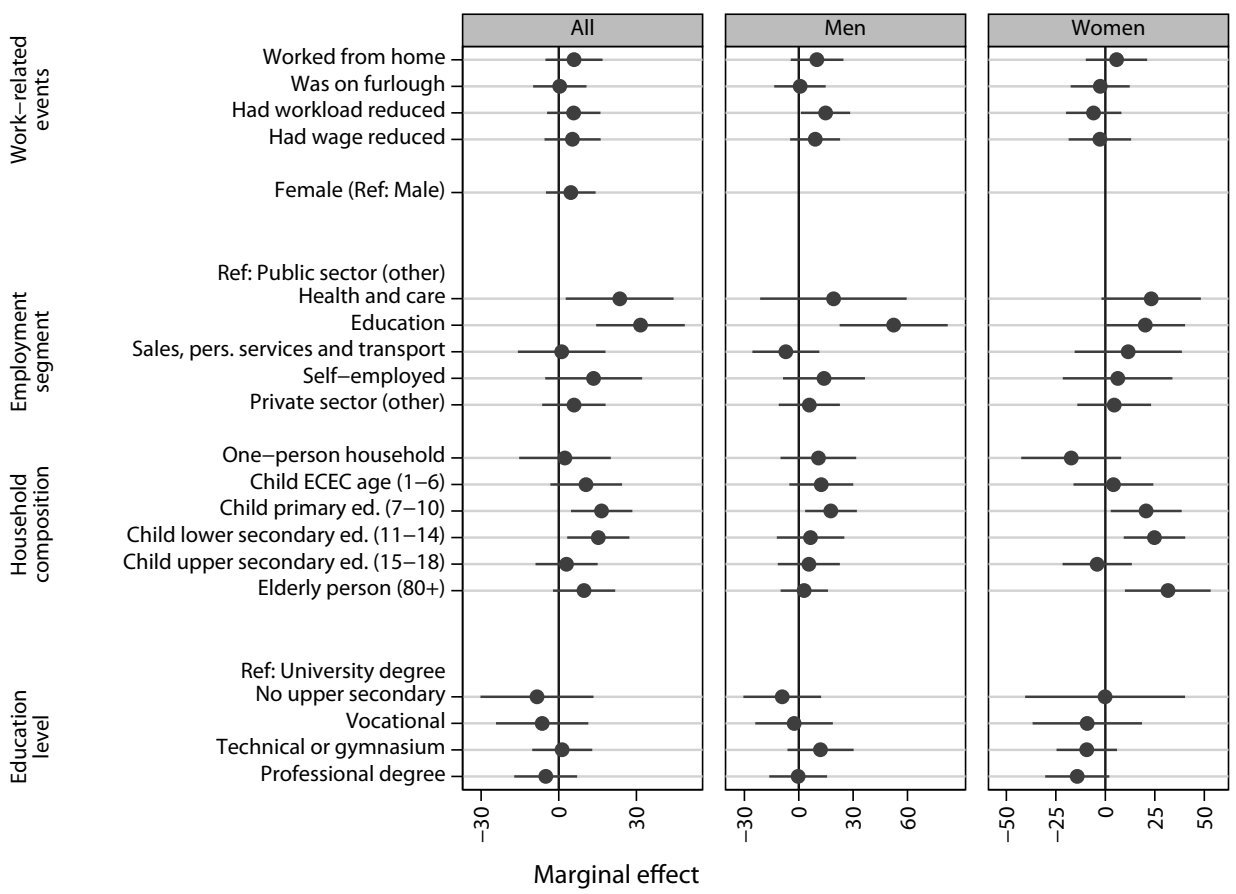

Note: Marginal effects in percentage points with their $95 \%$ confidence intervals holding other covariates at means. Underlying logistic regression shown in Table A3. 


\subsection{Earnings}

The impact of COVID-19 on earnings was measured at the job level (in terms of wage reduction) and household level (change in disposable income). Among employment segments, there was a clear pattern of self-employed being worst-off by both criteria, and of other private sector employees being more likely to report wage drop (but not deterioration of household income) compared to public sector employees. This difference is persistent even when controlling for demographics and education (Annex Table A4). As for other demographic traits, no significant effects on income loss were identified with respect to gender, education or household composition, yet deterioration was more likely among workers in the middle of their careers (age 40-49).

Table 2.

Income disruptions, perceived gravity of situation and health-related outcomes, by employment segment

\begin{tabular}{|c|c|c|c|c|c|c|c|}
\hline & \multirow[b]{2}{*}{$\mathrm{N}$} & \multirow[b]{2}{*}{$\begin{array}{l}\text { Had wage } \\
\text { reduced } \\
(\%)\end{array}$} & \multirow[b]{2}{*}{$\begin{array}{c}\text { Decrease } \\
\text { in house- } \\
\text { hold } \\
\text { income } \\
(\text { mean) } \\
(-2-2)^{\text {a }}\end{array}$} & \multirow[b]{2}{*}{$\begin{array}{c}\text { Perceived } \\
\text { gravity of } \\
\text { situation } \\
\text { (mean) } \\
(0-5)\end{array}$} & \multicolumn{2}{|c|}{ Contact with COVID-19 } & \multirow[b]{2}{*}{$\begin{array}{c}\text { Self- } \\
\text { reported } \\
\text { health } \\
\text { dete- } \\
\text { rioration } \\
\text { due to } \\
\text { pandemic } \\
(\%)\end{array}$} \\
\hline & & & & & $\begin{array}{c}\text { Was } \\
\text { ordered } \\
\text { to isolate } \\
(\%)\end{array}$ & $\begin{array}{c}\text { Knew an } \\
\text { infected } \\
\text { person } \\
\text { person- } \\
\text { ally }(\%)\end{array}$ & \\
\hline Total & 682 & 24.5 & 0.3 & 2.4 & 7.6 & 32.4 & 38.2 \\
\hline Health and care & 56 & 16.7 & 0.3 & 2.5 & 8.6 & 41.1 & 35.9 \\
\hline Education & 75 & 15.2 & 0.2 & 2.5 & 4.9 & 48.2 & 48.8 \\
\hline $\begin{array}{l}\text { Sales, personal ser- } \\
\text { vices and transport }\end{array}$ & 57 & 34.6 & 0.5 & 2.5 & 11.5 & 41.7 & 41.5 \\
\hline Self-employed & 67 & 56.7 & 0.5 & 2.3 & 16.0 & 28.9 & 36.7 \\
\hline $\begin{array}{l}\text { Public sector } \\
\text { (other) }\end{array}$ & 167 & 12.1 & 0.3 & 2.2 & 7.5 & 33.3 & 37.7 \\
\hline $\begin{array}{l}\text { Private sector } \\
\text { (other) }\end{array}$ & 260 & 24.4 & 0.2 & 2.4 & 5.1 & 26.7 & 36.9 \\
\hline
\end{tabular}

Note: a"Scale centered at "no change" value.

In order to understand work-related circumstances leading to wage and income reduction, we have included in the model the three disruptions pertaining to work organization (work from home, being on furlough, decrease in workload), as well as being subject to wage subsidy. With respect to both earnings indicators, having been furloughed and having workload decreased were associated with income deterioration (consistent with Eurostat, 2020). Working from home (unlike in Adams-Prasel et al, 2020) had negative statistically significant effect, but only on household income (as 
home-workers were often deduced transport supplement, which is technically not counted as wage reduction). Furthermore, having received state subsidies had a distinct negative effect (with little evidence of multicollinearity with other work-related events, to be expected as none were mandated), on both wage and household income. This was to be expected, as financial distress was one of the criteria for allocation of subsidies, whereas subsidy level was close to minimal wage and replacement rate not linked to worker wage.

After including work-related events as covariates, only the self-employed remained standing out in terms of having wage reduced and in decreased household income (Figure 4). As we could not identify an effect distinguishing any employee segment (in either private or public sector) once work-related disruptions and policies were accounted for, we can tentatively conclude that both furloughs and reduced workload contributed to wage reduction. Targeting, implementation and level of government subsidies resulted in them being present in workplaces where wages have decreased, while not being generous enough to offset other negative developments.

Figure 4.

Earning loss with respect to employment segment, demographics and work-related events

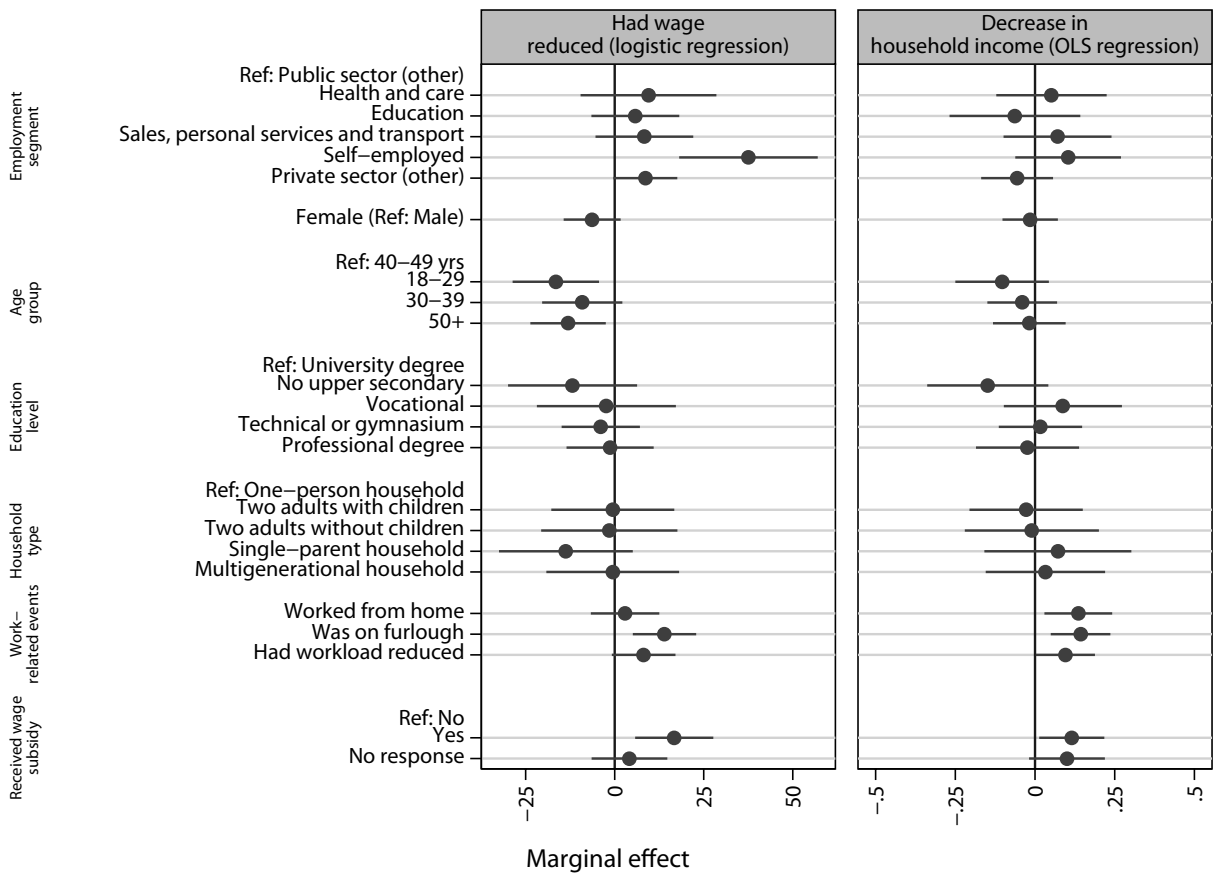

Note: Marginal effects with their 95\% confidence intervals holding other covariates at means. Underlying regressions shown in Table A4. 


\subsection{Resilience}

Experiences lived in the sphere of work seem to resonate with respondents' perception of the gravity of situation and life amidst the pandemic (Figure 5 below; Annex Table A5), albeit weakly (adj. $\mathrm{R}^{2}=0.046$ ). After controlling for demographics, there are two workplace-related events associated with a higher level of concern: having workload reduced and having work-life balance worsened. On the other hand, being supported with state wage subsidy was associated with a more favourable perception of current situation. Net of this, we've identified few differences at the level of employment segments, with non-frontline public sector workers being somewhat less concerned than non-shuttered private sector employees. This is slightly puzzling, as employment segments were defined in this paper exactly for being distinctly affected by the epidemic restrictions (health, education, self-employed and shuttered sales, services and transport).

Figure 5.

Perceived gravity of situation with respect to employment segment, work-related events and demographics

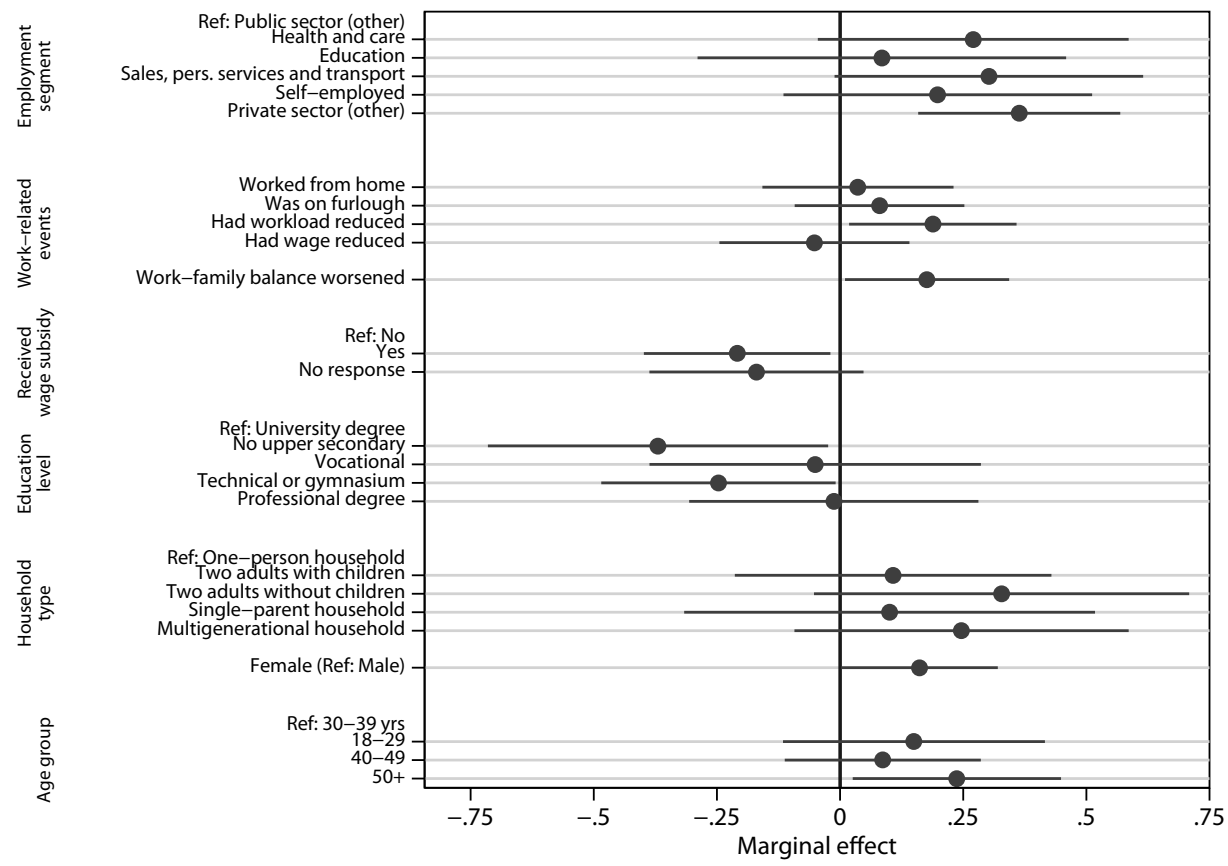

Note: Marginal effects with their $95 \%$ confidence intervals holding other covariates at means. Underlying regression shown in Table A5. 


\subsection{Health}

With respect to the three health-related outcomes analysed here: direct contact leading to isolation, social contact and health deterioration, the observed differences between the employment segments are modest (Table 2). After controlling for demographics and household composition, in no case could we infer differences between the baseline health and care sector and other segments of the workforce (Figure 6; Table A6, Annex). However, such finding pertains to a situation where COVID infection is a rare event, seldom experienced at personal level ${ }^{8}$. As for workplace events, not having workload reduced turned out to contribute to getting exposed to COVID-19 and being ordered to isolate, yet it is puzzling that having worked from home was not associated with lower risk of self-isolation. As importantly, having experience of working from home and increased difficulties in managing work-life balance both contributed to workers reporting health deterioration.

Figure 6.

Health-related outcomes with respect to employment segment and demographics

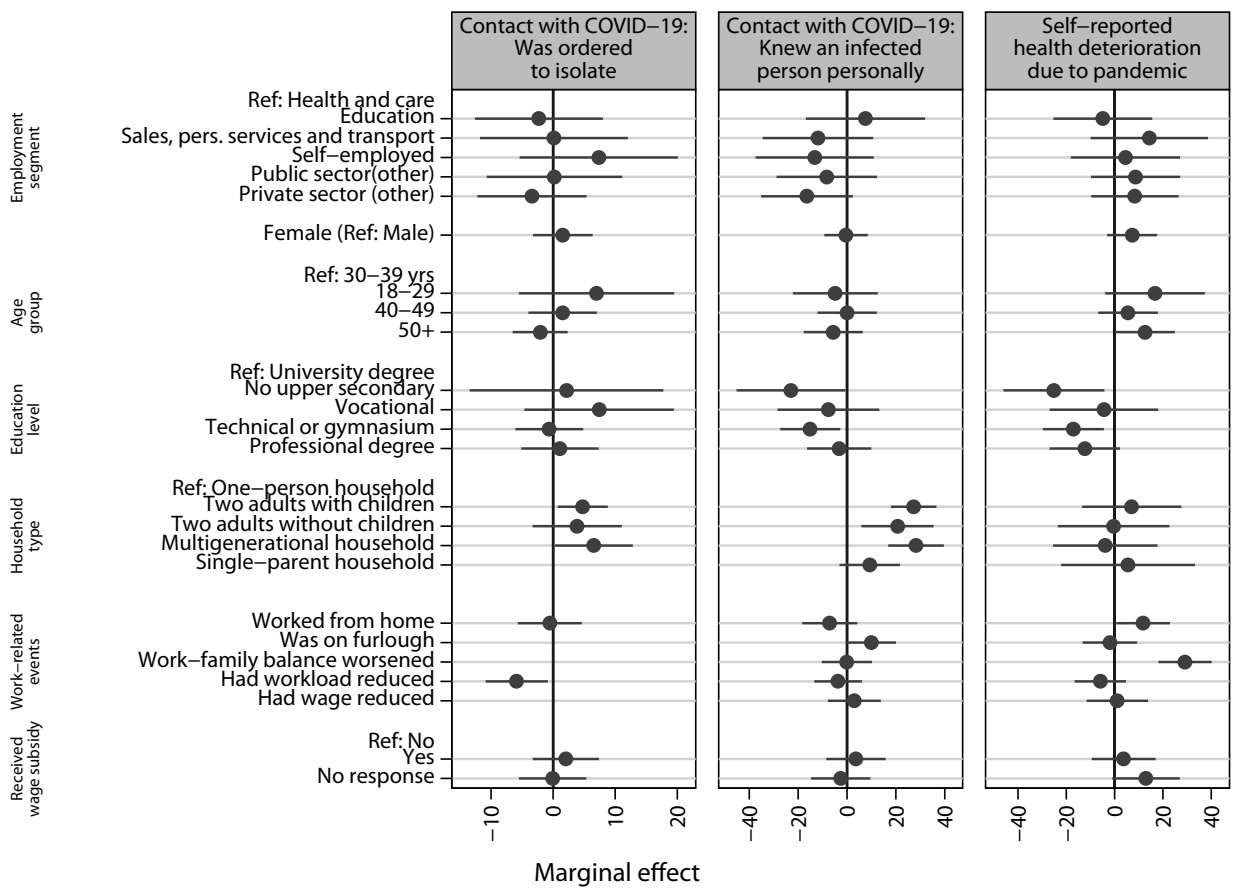

Note: Marginal effects in percentage points with their $95 \%$ confidence intervals holding other covariates at means. Underlying logistic regressions shown in Table A6.

8 At the time of fieldwork, as on October 1 only about $0.4 \%$ of population was diagnosed by that time and 71 per million has perished. 


\section{Conclusion}

The first wave of the COVID-19 pandemic induced work-related changes for six out of seven workers in Croatia, with one quarter reporting earnings loss. Different segments of workforce were affected in a different fashion, in line with the regulation of work and life during the lockdown and setup of supportive measures. Health and care workers did not face increased workload during the initial wave, but had to work in their hospitals/institutions and follow stringent procedures, and thus faced increasing work-family challenges, as schools and kindergartens were closed with little "emergency" capacity. Education workers were least likely to report having their workload reduced, and have almost universally switched their contact-intensive work to teleworking, contributing to work-family tension. Workers from the segments including sales, personal services and transport, commonly experienced furloughs (as many were shuttered during the lockdown), could generally not work from home, and were more likely to have their wage reduced. As far as other employees are concerned, those in the remainder of private sector did not stand out with respect to work-related events, but were more likely to have their wage reduced and were more concerned than their peers working in public sector. Similar to several international studies, we identified that the self-employed, though broadly supported by subsidies, were most likely to report decreasing earnings and workload.

The variation in experience of work during the pandemic for different socioeconomic groups was not overwhelming. As in most other studies, an education gradient was identified, as more educated were less likely to be put on furlough and more likely to work from home, but not much evidence on other dimensions. There is little evidence of young or old workers faring differently with respect to workplace changes during the pandemic. Insofar there was variation in work-related events by age group, young and old workers were less likely to report wage loss if they managed to keep their jobs, contrary to findings from Canada, Germany and UK (Beland et al, 2020; Holst et al, 2020; Crossley et al, 2021). As for the gender dimension, women were more likely to have their workload reduced and to be working from home, most likely due to occupational segregation being such that women are more likely both to have jobs directly affected by lockdown (personal services, sales, culture) and those (professional, administrative) more prone to teleworking, whereas there are fewer women in industrial occupations. Moreover, women faced increasing challenges in managing work-life balance as they comprise a majority of workforce in education, health and care sectors. We must heed that the gender impact of the crisis is largely dependent on the design, access and effect of interventions designed to counter it (Cook and Grimshaw, 2020).

Telework practices have made major inroads during the first wave of the pandemic, in part due to a switch to remote teaching, in part due to restrictions in public transport, and in part due to organizations following the regulations stipulating that workers should work from home when possible, which remained in force even after the lock- 
down ceased. Working from home was widely adopted in teleworkable occupations, yet the majority of respondents worked in jobs where telework cannot be implemented effectively, so only one third of workers actually had the experience of working from home. It is possible that regulating telework more favourably for workers and employers might make such practices more commonplace, but the requirements of many jobs for physical interaction or direct social interactions are likely to put limit to expansion, in particular in the Croatian economy heavily dependent on personal services.

The work-life balance proved as a challenge across the board to families with schoolaged children once schools ceased providing on-site education. Notably, neither working from home, being on furlough nor having reduced workload did buffer this disruption. While during the second wave of the pandemic school transitions to online teaching were applied selectively and in most cases targeted upper secondary education, our findings indicate that any enacted policies ought to provide adequate support for parents and adequate in-school capacity for children of key workers.

As for reductions in earnings, both at the personal and household level, those were consistently more likely when any of the observed workplace-related changes emerged: furlough periods, reduced workload, or working from home, and when subsidies were received. The existing wage subsidies paid to many employers, while targeting firms facing lower turnover and lockdown, did not contain the instruments to assure complete earning replacement.

As for resilience, changes experienced in the world of work did reflect on the respondents' level of concern about the gravity of situation caused by COVID-19. While unlike Kuhn et al. (2020) we found no direct effect of wage reduction, having workload reduced and experiencing deterioration in work-life balance both contributed to the level of concern, as did being employed in private sector. Yet the experience of state support via wage subsidies went some way to reduce the concern.

While $8 \%$ of workers have experienced mandated isolation and 38\% reported deteriorating health during the first wave of the pandemic, the differences between employment segments (and contribution of other sociodemographic traits) seem modest. Yet, workers continuing to work at "full pace" were more likely to get in contact with COVID-19 and self-isolate. Additionally, in line with findings from research dating prior to the pandemic (Eurofound 2020a; Lunau et al, 2014), workers facing difficulties in managing work-life balance and having to work from home were more likely to report deteriorating health during the pandemic.

In the context of restrictions and support measures enacted during the first wave of the COVID-19 pandemic in Croatia, our findings indicate widespread disruptions. However, unlike Holst et al (2020), we did not find overwhelming evidence of hori- 
zontal differentiation and vertical stratification of economic and health risks during the COVID-19 pandemic. We found few inequalities between employment segments beyond obvious ones (such as education workers switching to telework, many sales and personal service workers being ordered to furlough, or private sector employees being recipients of subsidies). There were not many differences between different employment segments with respect to earnings, resilience and health outcomes, yet there is evidence of adverse effect of work-related disruptions on those outcomes. Broad state support via wage subsidies has prevented job losses and reassured workers, yet was insufficient to compensate fully, in particular for the self-employed. The necessity of robust and effective lockdown-proof public education and care services came to fore during the initial wave of the pandemic as all the workers had to engage in providing those within the family, leading to increasing work-life balance challenges (in particular for health and education workers).

There are several limitations inherent in our effort. We have not accounted for the entire labour force, but only for those persisting in the workplace, thus side-lining a small but vulnerable part of workers who lost their job, or those aspiring and failing to find a seasonal job (such as many students-workers), or those languishing in unemployment. Second, our inferences are conservative by design, as a number of respondents is rather small, in particular for specific employment segments, and thus lacks statistical power to identify small differences. Third, the events are reported retrospectively and in broadest terms only, relying upon self-reporting, hindering both precision and causality inference. This is pertinent as international literature often had a number of respondents a degree of magnitude higher. Fourth, the insights relate to the first, smaller, wave of the pandemic in Croatia only. Whereas the first two issues are beyond addressing using this research design, the latter two will be addressed by follow-up panel waves throughout the 2021, examining further development among the initial set of respondents.

\section{References}

1. Adams-Prassl, A.; Boneva, T.; Golin, M.; Rauh, C. (2020). Inequality in the impact of the coronavirus shock: Evidence from real time surveys. Journal of Public Economics, 189, Article 104245. https://doi.org/10.1016/j.jpubeco.2020.104245.

2. Beland, L.-P.; Brodeur, A.; Wright, T.; Mikola, D. (2020). The short-term Economic Consequences of COVID-19: Occupation Tasks and Mental Health in Canada (IZA Discussion Paper No. 13254). Bonn (DE): IZA Institute of Labour Economics. http://ftp.iza.org/dp13254.pdf. (Retrieved 20th January 2021)

3. Beland, L.-P.; Fakorede, O. and Mikola, D. (2020). The Short-Term Effect of COVID-19 on Self-Employed Workers in Canada. Canadian Public Policy, 46(S1): S66-S81. 
4. Belot, M.; Choi, S.; Jamison, J. C.; Papageorge, N. W.; Tripodi, E.; van den Broek-Altenburg, E. (2020). Six-Country Survey on COVID-19 (IZA Discussion Paper No. 13230). Bonn (DE): IZA Institute of Labour Economics. http://ftp. iza.org/dp13230.pdf. (Retrieved 20th January 2021)

5. Cook, R.; and Grimshaw, D. (2020). A gendered lens on COVID-19 employment and social policies in Europe. European Societies. Advance online publication. https://doi.org/10.1080/14616696.2020.1822538.

6. Crossley, T. F.; Fisher, P. and Low, H. (2021). The heterogeneous and regressive consequences of COVID-19: Evidence from high quality panel data. Journal of Public Economics, 193, Article 104334. https://doi.org/10.1016/j.jpubeco.2020.104334.

7. Državni zavod za statistiku (2021). Zaposlenost - administrativni izvori. Statistika u nizu. Zagreb: Državni zavod za statistiku. https://www.dzs.hr/Hrv_Eng/ Pokazatelji/Zaposlenost\%20i\%20place/Zaposlenost $\% 20-\% 20$ Administrativni\%20izvori.xlsx. (Retrieved 10th January 2021)

8. Eesti Töötukassa [Estonian Unemployment Insurance Fund] (2020). Temporary subsidy program. https://www.tootukassa.ee/eng/content/subsidies-and-benefits/temporary-subsidy-program. (Retrieved 9 January 2021)

9. Eurofond [European Foundation for the Improvement of Living and Working Conditions] (2020). Living, working and COVID-19. Luxembourg: Publications Office of the European Union. https://data.europa.eu/doi/10.2806/467608.

10. Eurfound [European Foundation for the Improvement of Living and Working Conditions] (2020a). Telework and ICT-based mobile work: Flexible working in the digital age. Luxembourg: Publications Office of the European Union. doi:10.2806/337167.

11. European Commision (2020). Policy measures taken against the spread and impact of the coronavirus - 20 August 2020. https://ec.europa.eu/info/sites/info/ files/coronovirus-policy-measures-8-december en.pdf. (Retrieved $28^{\text {th }}$ December 2020)

12. Eurostat (2020, October). Impact of COVID-19 on employment income - Advanced estimates. https://ec.europa.eu/eurostat/statistics-explained/index. php?title=Impact of COVID-19 on employment income _ advanced estimates\&stable=1\#A sharp decrease in the median employment income. (Retrieved $20^{\text {th }}$ January 2021)

13. Hale, T.; Atav, T.; Hallas, L.; Beatriz, K.; Phillips, T.; Petherick, A.; Pott, A. (2020). Oxford COVID-19 Government Response Tracker. Blavatnik School of Government. https://www.bsg.ox.ac.uk/research/research-projects/coronavirusgovernment-response-tracker. (Retrieved $20^{\text {th }}$ January 2021)

14. Hipp, L. \& Bünning, M. (2020). Parenthood as a driver of increased gender inequality during COVID-19? Exploratory evidence from Germany. European Societies, Advance online publication. https://doi.org/10.1080/14616696.2020 .1833229 . 
15. Holst, H.; Fessler, A. and Niehoff, S. (2020). COVID-19, social class and work experience in Germany: Inequalities in work-related health and economic risks. European Societies, Advance online publication. https://doi.org/10.1080/14616 696.2020.1828979.

16. Hrvatski zavod za zapošljavanje [Croatian Employment Service] (2020). Popis korisnika potpore za poduzetnike u djelatnostima pogodenima koronavirusom. https://mjera-orm.hzz.hr/korisnici-potpore. (Retrieved $11^{\text {th }}$ November 2020)

17. Hrvatski zavod za zapošljavanje [Croatian Employment Service] (2021). Statistika On-Line. https://statistika.hzz.hr/. (Retrieved $11^{\text {th }}$ January 2021)

18. Kuhn, U.; Klaas, H. S.; Antal, E.; Dasoki, N.; Lebert, F.; Lipps, O.; Monsch, G.-A.; Refle, J.-E.; Ryser, V.-A.; Tillmann, R.; Voorpostel, M. (2020). Who is most affected by the Corona crisis? An analysis of changes in stress and wellbeing in Switzerland. European Societies, Advance online publication. https:// doi.org/10.1080/14616696.2020.1839671.

19. Lu, M. (2020, April). The Front Line: Visualizing the Occupations with the Highest COVID-19 Risk. Visual Capitalist. https:/www.visualcapitalist.com/ the-front-line-visualizing-the-occupations-with-the-highest-covid-19-risk/. (Retrieved 20 ${ }^{\text {th }}$ January 2021)

20. Lunau, T., Bambra, C., Eikemo, T. A., van der Wel, K. A., \& Dragano, N. (2014). A balancing act? Work-life balance, health and well-being in European welfare states. European Journal of Public Health, 24 (3): 422-427. https://doi. org/10.1093/eurpub/cku010.

21. Lyttelton, T. and Zang, E. (2020). Sickness-related Absences During the COVID-19 Pandemic: The Role of Occupations. SocArXiv. https://doi. org/10.31235/osf.io/adm36.

22. Möhring, K.; Naumann, E.; Reifenscheid, M.; Blom, A. G.; Wenz, A.; Rettig, T.; Lehrer, R.; Krieger, U.; Juhl, S.; Friedel, S. (2020a). Inequality in employment during the Corona lockdown: Evidence from Germany. JESP European Social Policy Blog. https://uni-tuebingen.de/en/fakultaeten/wirtschafts-undsozialwissenschaftliche-fakultaet/faecher/fachbereich-sozialwissenschaften/politikwissenschaft/institut/lehrende/comparative-public-policy-professor-seeleibkaiser/journal-of-european-social-policy/jesp-european-social-policy-blog/ newsfullview-jesp/article/inequality-in-employment-during-the-corona-lockdown-evidence-from-germany/. (Retrieved $20^{\text {th }}$ January 2021)

23. Möhring, K.; Naumann, E.; Reifenscheid, M.; Wenz, A.; Rettig, T.; Krieger, U.; Friedel, S.; Finkel, M.; Cornesse, C.; Blom, A. G. (2020b). The COVID-19 pandemic and subjective well-being: Longitudinal evidence on satisfaction with work and family. European Societies, Advance online publication. https://doi.or g/10.1080/14616696.2020.1833066.

24. Office for National Statistics UK (2020a). Coronavirus (COVID-19) related deaths by occupation, England and Wales. https://www.ons.gov.uk/peoplepopulationandcommunity/healthandsocialcare/causesofdeath/bulletins/coronaviruscovid19relateddeathsbyoccupationenglandandwales/deathsregisteredbetween9marchand 25 may 2020. 
25. OECD [Organisation for Economic Co-operation and Development] (2020, October). Job retention schemes during the COVID-19 lockdown and beyond (OECD Policy Response Series). https://read.oecd-ilibrary.org/view/?ref=135 1354156bardplc5q\&title=Job-retention-schemes-during-the-COVID-19-lockdownand-beyond. (Retrieved $12^{\text {th }}$ January 2021)

26. Reichelt, M.; Makovi, K. and Sargsyan, A. (2020). The impact of COVID-19 on gender inequality in the labor market and gender-role attitudes. European Societies, Advance online publication. https://doi.org/10.1080/14616696.202 $\underline{0.1823010 .}$.

27. Schröder, C.; Entringer, T.; Goebel, J.; Grabka, M. M.; Graeber, D.; Kroh, M.; Kröger, H.; Kühne, S.; Liebig, S.; Schupp, J.; Seebauer, J.; Zinn, S. (2020). COVID-19 Is Not Affecting All Working People Equally (SOEP papers on Multidisciplinary Panel Data Research, No. 1083). Berlin (DE): DIW Berlin, The German Socio-Economic Panel (SOEP). https://ideas.repec.org/p/diw/diwsop/ diw sp1083.html. (Retrieved 20 ${ }^{\text {th }}$ January 2021)

28. Sostero, M.; Milasi, S.; Hurley, J.; Fernandez-Macias, E.; Bisello, M. (2020). Teleworkability and the COVID-19 crisis: A new digital divide? (A Joint European Commission-Eurofound Report, JRC121193 ). Seville (ES): European Commission. 20 $0^{\text {th }}$ January 2021 https://ec.europa.eu/jrc/sites/jrcsh/files/jrc121193. pdf.

29. St-Denis, X. (2020). Sociodemographic Determinants of Occupational Risks of Exposure to COVID-19 in Canada. SocArXiv. https://doi.org/10.31235/osf. io/nrjd3.

30. Tavares, A. I. (2017). Telework and health effects review. International Journal of Healthcare, 3 (2): 30.

31. Von Gaudecker, H.-M.; Holler, R.; Janys, L.; Siflinger, B.; Zimpelmann, C. (2020). Labour supply in the early stages of the COViD-19 Pandemic: Empirical Evidence on hours, home office, and expectations (IZA Discussion Paper No. 13158). Bonn (DE): IZA Institute of Labour Economics. http://ftp.iza.org/ dp13158.pdf. (Retrieved 20 January 2021)

32. Zoch, G.; Bächmann, A.-C. \& Vicari, B. (2020). Who cares when care closes? Care-arrangements and parental working conditions during the COVID-19 pandemic in Germany. European Societies, Advance online publication. https:// doi.org/10.1080/14616696.2020.1832700. 


\section{Annex}

Table A1a.

Outcome variables with respect to demographics and employment segment

\begin{tabular}{|c|c|c|c|c|c|c|}
\hline & $z$ & 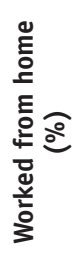 & 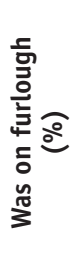 & 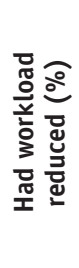 & 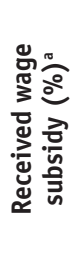 & 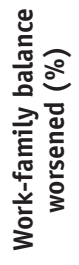 \\
\hline Total & 682 & 33.7 & 36.8 & 36.0 & 33.8 & 32.0 \\
\hline \multicolumn{7}{|l|}{ Gender: } \\
\hline Male & 299 & 29.1 & 35.9 & 30.3 & 36.3 & 27.7 \\
\hline Female & 383 & 38.9 & 37.7 & 42.3 & 30.9 & 36.7 \\
\hline \multicolumn{7}{|l|}{ Age group: } \\
\hline $18-29$ & 48 & 24.1 & 35.8 & 37.3 & 42.9 & 26.9 \\
\hline $30-39$ & 129 & 34.9 & 36.7 & 33.3 & 36.2 & 38.1 \\
\hline $40-49$ & 227 & 35.8 & 38.3 & 40.7 & 37.9 & 34.4 \\
\hline $50+$ & 278 & 34.1 & 35.4 & 33.2 & 22.9 & 24.9 \\
\hline \multicolumn{7}{|l|}{ Education level: } \\
\hline No upper secondary & 19 & 22.2 & 47.5 & 40.5 & 20.8 & 19.8 \\
\hline Vocational & 43 & 5.6 & 39.8 & 29.5 & 40.0 & 20.6 \\
\hline Technical or gymnasium & 282 & 22.2 & 40.9 & 39.9 & 40.4 & 35.0 \\
\hline Professional degree & 130 & 62.7 & 25.4 & 34.7 & 26.6 & 30.1 \\
\hline University degree & 208 & 72.4 & 24.1 & 26.3 & 21.8 & 37.0 \\
\hline \multicolumn{7}{|l|}{ Household type: } \\
\hline One-person household & 44 & 36.1 & 41.6 & 33.4 & 33.2 & 26.7 \\
\hline Two adults with children & 361 & 31.4 & 35.9 & 34.1 & 33.9 & 32.3 \\
\hline Two adults without children & 84 & 35.3 & 38.1 & 38.9 & 31.0 & 28.0 \\
\hline Single-parent household & 37 & 30.4 & 25.6 & 27.5 & 28.9 & 22.0 \\
\hline Multigenerational household & 156 & 38.4 & 39.9 & 41.6 & 36.0 & 37.0 \\
\hline \multicolumn{7}{|l|}{ Employment segment: } \\
\hline Health and care & 56 & 16.3 & 37.7 & 41.3 & 7.9 & 46.4 \\
\hline Education & 75 & 93.7 & 22.3 & 17.6 & 9.1 & 54.1 \\
\hline Sales, personal services and transport & 57 & 8.5 & 61.8 & 40.7 & 50.4 & 29.9 \\
\hline Self-employed & 67 & 52.6 & 45.1 & 49.6 & 43.9 & 38.4 \\
\hline Public sector(other) & 167 & 43.6 & 35.3 & 30.7 & 14.9 & 24.4 \\
\hline Private sector (other) & 260 & 26.2 & 31.3 & 36.0 & 45.0 & 29.4 \\
\hline
\end{tabular}

Note: a"No response" counted as not having received subsidy 
Table A1b.

Outcome variables with respect to demographics and employment segment

\begin{tabular}{|c|c|c|c|c|c|c|}
\hline & 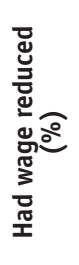 & 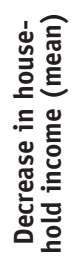 & 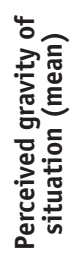 & 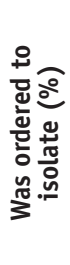 & 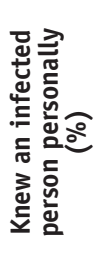 & 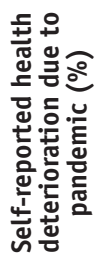 \\
\hline Total & 24.5 & 0.3 & 2.4 & 7.6 & 32.4 & 38.2 \\
\hline \multicolumn{7}{|l|}{ Gender: } \\
\hline Male & 27.8 & 0.3 & 2.3 & 7.6 & 31.3 & 34.4 \\
\hline Female & 20.9 & 0.3 & 2.5 & 7.6 & 33.7 & 42.4 \\
\hline \multicolumn{7}{|l|}{ Age group: } \\
\hline $18-29$ & 19.6 & 0.2 & 2.5 & 15.0 & 36.5 & 44.1 \\
\hline $30-39$ & 22.6 & 0.3 & 2.3 & 7.2 & 35.9 & 35.1 \\
\hline $40-49$ & 34.7 & 0.3 & 2.3 & 8.7 & 34.7 & 38.8 \\
\hline $50+$ & 17.6 & 0.3 & 2.5 & 3.9 & 24.7 & 38.4 \\
\hline \multicolumn{7}{|l|}{ Education level: } \\
\hline No upper secondary & 16.0 & 0.2 & 2.3 & 5.6 & 16.0 & 24.7 \\
\hline Vocational & 27.2 & 0.4 & 2.5 & 16.5 & 36.3 & 40.7 \\
\hline Technical or gymnasium & 26.4 & 0.3 & 2.3 & 6.3 & 30.2 & 35.1 \\
\hline Professional degree & 24.6 & 0.3 & 2.6 & 8.6 & 37.2 & 40.6 \\
\hline University degree & 21.9 & 0.3 & 2.5 & 7.2 & 42.8 & 51.5 \\
\hline \multicolumn{7}{|l|}{ Household type: } \\
\hline One-person household & 25.0 & 0.3 & 2.3 & 1.5 & 8.8 & 35.2 \\
\hline Two adults with children & 26.2 & 0.3 & 2.3 & 9.1 & 36.5 & 41.5 \\
\hline Two adults without children & 19.9 & 0.3 & 2.6 & 5.3 & 27.5 & 35.5 \\
\hline Single-parent household & 8.9 & 0.3 & 2.2 & 0.0 & 15.6 & 35.5 \\
\hline Multigenerational household & 27.1 & 0.3 & 2.5 & 9.1 & 36.2 & 33.9 \\
\hline \multicolumn{7}{|l|}{ Employment segment: } \\
\hline Health and care & 16.7 & 0.3 & 2.5 & 8.6 & 41.1 & 35.9 \\
\hline Education & 15.2 & 0.2 & 2.5 & 4.9 & 48.2 & 48.8 \\
\hline Sales, personal services and transport & 34.6 & 0.5 & 2.5 & 11.5 & 41.7 & 41.5 \\
\hline Self-employed & 56.7 & 0.5 & 2.3 & 16.0 & 28.9 & 36.7 \\
\hline Public sector(other) & 12.1 & 0.3 & 2.2 & 7.5 & 33.3 & 37.7 \\
\hline Private sector (other) & 24.4 & 0.2 & 2.4 & 5.1 & 26.7 & 36.9 \\
\hline
\end{tabular}


Table A2.

Logistic regressions: Work-related events with respect to employment segment, demographics and having received wage subsidy

\begin{tabular}{|c|c|c|c|c|c|c|c|c|}
\hline & \multicolumn{2}{|c|}{$\begin{array}{l}\text { Received wage } \\
\text { subsidy } \\
\text { (1) }\end{array}$} & \multicolumn{2}{|c|}{$\begin{array}{l}\text { Was on } \\
\text { furlough } \\
\text { (2) }\end{array}$} & \multicolumn{2}{|c|}{$\begin{array}{l}\text { Had workload } \\
\text { reduced } \\
\text { (3) }\end{array}$} & \multicolumn{2}{|c|}{$\begin{array}{l}\text { Worked from } \\
\text { home } \\
(4)\end{array}$} \\
\hline \multicolumn{9}{|l|}{ Employment segment: } \\
\hline Health and care & $-2.68^{* * *}$ & $(4.12)$ & -0.73 & $(1.42)$ & 0.04 & $(0.08)$ & -0.05 & $(0.06)$ \\
\hline Education & $-2.15^{* *}$ & (3.16) & $-1.03^{*}$ & $(2.01)$ & -0.94 & $(1.78)$ & $3.36^{* *}$ & $(4.43)$ \\
\hline Sales, personal services and transport (ref.) & 0.00 & (.) & 0.00 & (.) & 0.00 & (.) & 0.00 & (.) \\
\hline Self-employed & -0.45 & $(0.86)$ & -0.76 & (1.48) & 0.36 & $(0.74)$ & $2.49^{\cdots \cdots}$ & $(3.59)$ \\
\hline Public sector (other) & $-1.93^{* * *}$ & (3.54) & -0.82 & $(1.90)$ & -0.31 & $(0.73)$ & $1.49^{\circ}$ & (2.52) \\
\hline Private sector (other) & -0.31 & $(0.70)$ & $-1.37^{\cdots}$ & $(3.52)$ & -0.24 & $(0.63)$ & 1.11 & (1.96) \\
\hline \multicolumn{9}{|l|}{ Gender: } \\
\hline Female & 0.08 & $(0.31)$ & 0.07 & $(0.33)$ & 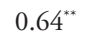 & (2.92) & $0.53^{*}$ & $(2.24)$ \\
\hline \multicolumn{9}{|l|}{ Age group: } \\
\hline $18-29$ & 0.35 & $(0.71)$ & 0.19 & $(0.38)$ & 0.24 & $(0.55)$ & -0.72 & $(1.60)$ \\
\hline 30-39 (ref.) & 0.00 & (.) & 0.00 & (.) & 0.00 & (.) & 0.00 & (.) \\
\hline $40-49$ & 0.23 & $(0.69)$ & 0.08 & $(0.28)$ & 0.29 & $(1.05)$ & -0.05 & $(0.14)$ \\
\hline $50+$ & -0.21 & $(0.60)$ & -0.05 & $(0.17)$ & 0.04 & $(0.13)$ & -0.03 & $(0.10)$ \\
\hline \multicolumn{9}{|l|}{ Education level: } \\
\hline No upper secondary & -0.06 & $(0.10)$ & $1.22^{*}$ & $(2.26)$ & 0.59 & $(1.10)$ & $-2.25^{* *}$ & (3.24) \\
\hline Vocational & 0.41 & $(0.78)$ & 0.27 & $(0.56)$ & -0.10 & $(0.20)$ & $-3.04^{* *}$ & $(4.70)$ \\
\hline Technical or grammar school & $0.83^{* *}$ & $(2.84)$ & $0.59^{*}$ & (2.14) & 0.40 & $(1.56)$ & $-1.96^{* * x}$ & (6.93) \\
\hline Professional degree & 0.22 & $(0.61)$ & 0.06 & $(0.19)$ & 0.35 & (1.19) & -0.26 & $(0.81)$ \\
\hline University degree (ref.) & 0.00 & (.) & 0.00 & (.) & 0.00 & (.) & 0.00 & (.) \\
\hline \multicolumn{9}{|l|}{ Received wage subsidy: } \\
\hline No (ref.) & & & 0.00 & (.) & 0.00 & (.) & 0.00 & (.) \\
\hline Yes & & & $0.98^{* * *}$ & $(3.50)$ & $0.73^{* *}$ & $(2.75)$ & $-0.80^{* *}$ & $(2.95)$ \\
\hline No response & & & 0.22 & $(0.67)$ & -0.20 & $(0.66)$ & -0.67 & $(1.75)$ \\
\hline Constant & -0.17 & $(0.34)$ & -0.52 & $(1.06)$ & $-1.38^{* \prime}$ & $(3.06)$ & -0.32 & $(0.54)$ \\
\hline Observations & \multicolumn{2}{|c|}{557} & \multicolumn{2}{|c|}{672} & \multicolumn{2}{|c|}{668} & \multicolumn{2}{|c|}{674} \\
\hline Pseudo $R^{2}$ & \multicolumn{2}{|c|}{0.144} & \multicolumn{2}{|c|}{0.079} & \multicolumn{2}{|c|}{0.064} & \multicolumn{2}{|c|}{0.286} \\
\hline BIC & \multicolumn{2}{|c|}{685.26} & \multicolumn{2}{|c|}{851.13} & \multicolumn{2}{|c|}{855.51} & \multicolumn{2}{|c|}{668.15} \\
\hline
\end{tabular}

Note: $z$ statistics in parentheses (absolute values), ${ }^{*} p<0.05,{ }^{* *} p<0.01,{ }^{* * * *} p<0.001$ 
Table A3.

Logistic regression: Deterioration of Work-family balance with respect to work-related events, employment segment and demographics

\begin{tabular}{|c|c|c|c|c|c|c|}
\hline & \multicolumn{2}{|c|}{$\begin{array}{l}\text { All } \\
(1)\end{array}$} & \multicolumn{2}{|c|}{$\begin{array}{c}\text { Women } \\
(2)\end{array}$} & \multicolumn{2}{|c|}{$\begin{array}{c}\text { Men } \\
(3)\end{array}$} \\
\hline \multicolumn{7}{|l|}{ Work-related events: } \\
\hline Worked from home & 0.28 & $(1.04)$ & 0.25 & $(0.71)$ & 0.57 & $(1.35)$ \\
\hline Was on furlough & 0.02 & $(0.08)$ & -0.11 & $(0.34)$ & 0.04 & $(0.09)$ \\
\hline Had workload reduced & 0.28 & $(1.10)$ & -0.26 & $(0.82)$ & $0.83^{*}$ & $(2.17)$ \\
\hline Had wage reduced & 0.25 & $(0.97)$ & -0.12 & $(0.34)$ & 0.51 & $(1.27)$ \\
\hline \multicolumn{7}{|l|}{ Employment segment: } \\
\hline Health and care & $1.07^{*}$ & $(2.24)$ & 1.00 & $(1.77)$ & 0.99 & $(1.04)$ \\
\hline Education & $1.39^{* * *}$ & $(3.57)$ & 0.88 & $(1.96)$ & $2.38^{* *}$ & $(3.02)$ \\
\hline Sales, personal services and transport & 0.06 & $(0.13)$ & 0.53 & $(0.86)$ & -0.59 & $(0.73)$ \\
\hline Self-employed & 0.66 & $(1.44)$ & 0.29 & $(0.45)$ & 0.76 & $(1.21)$ \\
\hline Public sector (other) (ref.) & 0.00 & (.) & 0.00 & (.) & 0.00 & (.) \\
\hline Private sector (other) & 0.31 & $(0.90)$ & 0.22 & $(0.47)$ & 0.36 & $(0.64)$ \\
\hline \multicolumn{7}{|l|}{ Gender: } \\
\hline Female & 0.22 & $(0.95)$ & & & & \\
\hline \multicolumn{7}{|l|}{ Education level: } \\
\hline No upper secondary & -0.43 & $(0.70)$ & -0.00 & $(0.01)$ & -0.75 & $(0.74)$ \\
\hline Vocational & -0.32 & $(0.68)$ & -0.39 & $(0.62)$ & -0.18 & $(0.24)$ \\
\hline Technical or grammar school & 0.06 & $(0.23)$ & -0.40 & $(1.21)$ & 0.65 & $(1.21)$ \\
\hline Professional degree & -0.25 & $(0.81)$ & -0.63 & $(1.65)$ & -0.02 & $(0.04)$ \\
\hline University degree (ref.) & 0.00 & (.) & 0.00 & (.) & 0.00 & (.) \\
\hline \multicolumn{7}{|l|}{ Household composition, including: } \\
\hline Single person household & 0.11 & $(0.27)$ & -0.76 & $(1.35)$ & 0.61 & $(1.00)$ \\
\hline Child ECEC age (1-6) & 0.50 & $(1.51)$ & 0.18 & $(0.40)$ & 0.70 & $(1.40)$ \\
\hline Child primary ed. (7-10) & $0.79^{* *}$ & $(2.75)$ & $0.91^{*}$ & $(2.28)$ & $1.00^{*}$ & $(2.39)$ \\
\hline Child lower secondary ed. (11-14) & $0.73^{*}$ & $(2.49)$ & $1.09^{* *}$ & $(3.12)$ & 0.37 & $(0.69)$ \\
\hline Child upper secondary ed. (15-18) & 0.14 & $(0.49)$ & -0.18 & $(0.46)$ & 0.31 & $(0.63)$ \\
\hline Elderly person $(80+)$ & 0.46 & $(1.58)$ & $1.39^{* *}$ & $(2.82)$ & 0.17 & $(0.46)$ \\
\hline Constant & $-1.94^{* * *}$ & $(4.54)$ & -1.04 & $(1.96)$ & $-2.78^{* * *}$ & $(3.80)$ \\
\hline Observations & \multicolumn{2}{|c|}{659} & \multicolumn{2}{|c|}{372} & \multicolumn{2}{|c|}{287} \\
\hline Pseudo $R^{2}$ & \multicolumn{2}{|c|}{0.095} & \multicolumn{2}{|c|}{0.103} & \multicolumn{2}{|c|}{0.169} \\
\hline$B I C$ & \multicolumn{2}{|c|}{820.29} & \multicolumn{2}{|c|}{452.51} & \multicolumn{2}{|c|}{427.63} \\
\hline
\end{tabular}

Note: $z$ statistics in parentheses (absolute values), ${ }^{*} p<0.05,{ }^{* *} p<0.01,{ }^{, * * *} p<0.001$ 
Table A4.

Earning loss with respect to employment segment, demographics and work-related events

\begin{tabular}{|c|c|c|c|c|c|c|c|c|}
\hline & \multicolumn{4}{|c|}{$\begin{array}{l}\text { Had wage reduced } \\
\text { (logistic regression) }\end{array}$} & \multicolumn{4}{|c|}{$\begin{array}{c}\text { Decrease in household income } \\
\text { (OLS regression) }\end{array}$} \\
\hline & \multicolumn{2}{|c|}{ (1) } & \multicolumn{2}{|c|}{$(2)$} & \multicolumn{2}{|c|}{ (3) } & \multicolumn{2}{|c|}{ (4) } \\
\hline \multicolumn{9}{|l|}{ Employment segment: } \\
\hline Health and care & 0.62 & $(1.06)$ & 0.72 & $(1.16)$ & 0.02 & $(0.28)$ & 0.05 & $(0.59)$ \\
\hline Education & 0.30 & $(0.64)$ & 0.48 & $(0.99)$ & -0.05 & $(0.44)$ & -0.06 & $(0.60)$ \\
\hline Sales, personal services and transport & $1.35^{* *}$ & $(2.70)$ & 0.65 & $(1.28)$ & 0.13 & $(1.52)$ & 0.07 & $(0.82)$ \\
\hline Self-employed & $2.27^{\cdots *}$ & $(4.99)$ & $2.01^{* *}$ & $(4.16)$ & $0.18^{*}$ & $(2.09)$ & 0.10 & $(1.23)$ \\
\hline Public sector (other) (ref.) & 0.00 & (.) & 0.00 & (.) & 0.00 & (.) & 0.00 & $()$. \\
\hline Private sector (other) & $0.89^{*}$ & $(2.45)$ & 0.67 & $(1.77)$ & -0.04 & $(0.75)$ & -0.06 & $(0.98)$ \\
\hline \multicolumn{9}{|l|}{ Gender: } \\
\hline Female & -0.26 & $(1.06)$ & -0.40 & $(1.56)$ & 0.01 & $(0.29)$ & -0.02 & $(0.34)$ \\
\hline \multicolumn{9}{|l|}{ Age group: } \\
\hline $18-29$ & $-0.90^{*}$ & $(1.99)$ & $-1.08^{*}$ & $(2.23)$ & -0.12 & $(1.53)$ & -0.10 & $(1.38)$ \\
\hline $30-39$ & -0.52 & $(1.62)$ & -0.51 & $(1.56)$ & -0.06 & $(1.04)$ & -0.04 & $(0.72)$ \\
\hline 40-49 (ref.) & 0.00 & $()$. & 0.00 & $()$. & 0.00 & $()$. & 0.00 & $()$. \\
\hline $50+$ & $-0.88^{* *}$ & $(2.99)$ & $-0.79^{*}$ & $(2.41)$ & -0.04 & $(0.73)$ & -0.02 & $(0.31)$ \\
\hline \multicolumn{9}{|l|}{ Education level: } \\
\hline No upper secondary & -0.66 & $(0.82)$ & -0.86 & $(1.01)$ & -0.15 & $(1.62)$ & -0.15 & (1.53) \\
\hline Vocational & -0.16 & $(0.29)$ & -0.14 & $(0.23)$ & 0.04 & $(0.42)$ & 0.09 & $(0.93)$ \\
\hline Technical or grammar school & 0.05 & $(0.18)$ & -0.23 & $(0.71)$ & 0.01 & $(0.14)$ & 0.02 & $(0.26)$ \\
\hline Professional degree & -0.04 & $(0.12)$ & -0.07 & $(0.20)$ & -0.02 & $(0.25)$ & -0.02 & $(0.28)$ \\
\hline University degree (ref.) & 0.00 & $()$. & 0.00 & $()$. & 0.00 & $()$. & 0.00 & $()$. \\
\hline \multicolumn{9}{|l|}{ Household type: } \\
\hline One-person household (ref.) & 0.00 & $()$. & 0.00 & $()$. & 0.00 & $()$. & 0.00 & (.) \\
\hline Two adults with children & -0.19 & $(0.34)$ & -0.03 & $(0.06)$ & -0.05 & $(0.53)$ & -0.03 & $(0.31)$ \\
\hline Two adults without children & -0.15 & $(0.23)$ & -0.09 & $(0.16)$ & -0.01 & $(0.08)$ & -0.01 & $(0.09)$ \\
\hline Single-parent household & -1.32 & $(1.64)$ & -1.19 & $(1.41)$ & 0.05 & $(0.41)$ & 0.07 & $(0.61)$ \\
\hline Multigenerational household & -0.09 & $(0.16)$ & -0.03 & $(0.06)$ & 0.04 & $(0.40)$ & 0.03 & $(0.34)$ \\
\hline \multicolumn{9}{|l|}{ Work-related events: } \\
\hline Worked from home & & & 0.19 & $(0.60)$ & & & $0.14^{*}$ & $(2.51)$ \\
\hline Was on furlough & & & $0.89^{* *}$ & $(3.00)$ & & & $0.14^{* *}$ & $(3.00)$ \\
\hline Had workload reduced & & & 0.52 & $(1.83)$ & & & $0.10^{*}$ & $(2.01)$ \\
\hline \multicolumn{9}{|l|}{ Received wage subsidy: } \\
\hline No (ref.) & & & 0.00 & (.) & & & 0.00 & (.) \\
\hline Yes & & & $1.01^{* *}$ & $(3.15)$ & & & $0.12^{*}$ & $(2.22)$ \\
\hline No response & & & 0.31 & $(0.81)$ & & & 0.10 & $(1.66)$ \\
\hline Constant & -1.19 & $(1.83)$ & $-2.00^{* *}$ & (2.88) & $0.34^{* *}$ & $(2.86)$ & 0.15 & $(1.19)$ \\
\hline Observations & \multicolumn{2}{|c|}{661} & \multicolumn{2}{|c|}{661} & \multicolumn{2}{|c|}{665} & \multicolumn{2}{|c|}{665} \\
\hline Pseudo $R^{2}\left(R^{2}\right)$ & \multicolumn{2}{|c|}{0.104} & \multicolumn{2}{|c|}{0.183} & \multicolumn{2}{|c|}{$(0.035)$} & \multicolumn{2}{|c|}{$(0.081)$} \\
\hline BIC & \multicolumn{2}{|c|}{718.21} & \multicolumn{2}{|c|}{697.64} & & & & \\
\hline
\end{tabular}

Note: $z / t$ statistics in parentheses (absolute values), ${ }^{*} p<0.05,{ }^{* *} p<0.01,{ }^{* * *} p<0.001$ 
Table A5.

OLS regression: Perceived gravity of situation with respect to employment segment, work-related events and demographics

\begin{tabular}{|c|c|c|c|c|}
\hline & \multicolumn{2}{|c|}{$(1)$} & \multicolumn{2}{|c|}{ (2) } \\
\hline \multicolumn{5}{|l|}{ Employment segment: } \\
\hline Health and care & $0.31^{*}$ & $(1.99)$ & 0.27 & $(1.68)$ \\
\hline Education & 0.12 & $(0.65)$ & 0.08 & $(0.44)$ \\
\hline Sales, personal services and transport & 0.26 & $(1.67)$ & 0.30 & $(1.89)$ \\
\hline Self-employed & 0.22 & $(1.45)$ & 0.20 & $(1.24)$ \\
\hline Public sector (other) (ref.) & 0.00 & $()$. & 0.00 & $()$. \\
\hline Private sector (other) & $0.32^{* *}$ & $(3.17)$ & $0.36^{* * *}$ & $(3.48)$ \\
\hline \multicolumn{5}{|l|}{ Gender: } \\
\hline Female & $0.21^{*}$ & (2.61) & $0.16^{*}$ & $(2.00)$ \\
\hline \multicolumn{5}{|l|}{ Age group: } \\
\hline $18-29$ & 0.13 & $(0.95)$ & 0.15 & $(1.11)$ \\
\hline $30-39$ & 0.00 & $()$. & 0.00 & $()$. \\
\hline 40-49 (ref.) & 0.08 & $(0.75)$ & 0.09 & $(0.86)$ \\
\hline $50+$ & $0.21^{*}$ & $(1.97)$ & $0.24^{*}$ & $(2.20)$ \\
\hline \multicolumn{5}{|l|}{ Education level: } \\
\hline No upper secondary & $-0.36^{*}$ & (2.13) & $-0.37^{*}$ & $(2.10)$ \\
\hline Vocational & -0.10 & $(0.62)$ & -0.05 & $(0.29)$ \\
\hline Technical or grammar school & $-0.26^{\circ}$ & $(2.31)$ & $-0.25^{*}$ & $(2.04)$ \\
\hline Professional degree & -0.02 & $(0.11)$ & -0.01 & $(0.09)$ \\
\hline University degree (ref.) & 0.00 & $()$. & 0.00 & $()$. \\
\hline \multicolumn{5}{|l|}{ Household type: } \\
\hline One-person household (ref.) & 0.00 & $()$. & 0.00 & $()$. \\
\hline Two adults with children & 0.12 & $(0.72)$ & 0.11 & $(0.66)$ \\
\hline Two adults without children & 0.35 & $(1.79)$ & 0.33 & $(1.69)$ \\
\hline Single-parent household & 0.07 & $(0.33)$ & 0.10 & $(0.47)$ \\
\hline Multigenerational household & 0.29 & $(1.66)$ & 0.25 & $(1.43)$ \\
\hline \multicolumn{5}{|l|}{ Work-related events: } \\
\hline Worked from home & & & 0.04 & $(0.37)$ \\
\hline Was on furlough & & & 0.08 & $(0.91)$ \\
\hline Work-family balance worsened & & & $0.18^{*}$ & $(2.08)$ \\
\hline Had workload reduced & & & $0.19^{*}$ & $(2.18)$ \\
\hline Had wage reduced & & & -0.05 & $(0.53)$ \\
\hline \multicolumn{5}{|l|}{ Received wage subsidy: } \\
\hline No (ref.) & & & 0.00 & $()$. \\
\hline Yes & & & $-0.21^{*}$ & $(2.17)$ \\
\hline No response & & & -0.17 & $(1.53)$ \\
\hline Constant & $1.98^{* *+}$ & $(9.73)$ & $1.92^{\cdots *}$ & $(8.93)$ \\
\hline Observations & \multicolumn{2}{|c|}{659} & \multicolumn{2}{|c|}{659} \\
\hline$R^{2}$ & \multicolumn{2}{|c|}{0.054} & \multicolumn{2}{|c|}{0.081} \\
\hline Adjusted $R^{2}$ & \multicolumn{2}{|c|}{0.028} & \multicolumn{2}{|c|}{0.046} \\
\hline
\end{tabular}

Note: $t$ statistics in parentheses (absolute values), ${ }^{*} p<0.05,{ }^{* *} p<0.01,{ }^{* * *} p<0.001$ 
Table A6.

Health-related outcomes with respect to employment segment, work-related events and demographics

\begin{tabular}{|c|c|c|c|c|c|c|}
\hline & \multicolumn{4}{|c|}{ Contact with COVID-19 } & \multirow{2}{*}{\multicolumn{2}{|c|}{$\begin{array}{l}\text { Self-reported health } \\
\text { deterioration due to } \\
\text { pandemic }\end{array}$}} \\
\hline & \multicolumn{2}{|c|}{$\begin{array}{l}\text { Was ordered to } \\
\text { isolate }\end{array}$} & \multicolumn{2}{|c|}{$\begin{array}{l}\text { Knew an infected } \\
\text { person personally }\end{array}$} & & \\
\hline & \multicolumn{2}{|c|}{$(1)$} & \multicolumn{2}{|c|}{$(2)$} & \multicolumn{2}{|c|}{ (3) } \\
\hline \multicolumn{7}{|l|}{ Employment segment: } \\
\hline Health and care & 0.00 & (.) & 0.00 & (.) & 0.00 & (.) \\
\hline Education & -0.41 & $(0.45)$ & 0.31 & $(0.60)$ & -0.25 & $(0.47)$ \\
\hline Sales, personal services and transport & 0.02 & $(0.02)$ & -0.53 & $(1.03)$ & 0.62 & $(1.15)$ \\
\hline Self-employed & 0.78 & $(1.04)$ & -0.59 & $(1.06)$ & 0.20 & $(0.39)$ \\
\hline Public sector (other) (ref.) & 0.03 & $(0.04)$ & -0.36 & $(0.80)$ & 0.39 & $(0.89)$ \\
\hline Private sector (other) & -0.67 & $(0.92)$ & -0.75 & $(1.82)$ & 0.37 & $(0.87)$ \\
\hline \multicolumn{7}{|l|}{ Gender: } \\
\hline Female & 0.28 & $(0.64)$ & -0.02 & $(0.09)$ & 0.31 & $(1.37)$ \\
\hline \multicolumn{7}{|l|}{ Age group: } \\
\hline $18-29$ & 0.89 & $(1.42)$ & -0.23 & $(0.53)$ & 0.72 & $(1.62)$ \\
\hline 30-39 (ref.) & 0.00 & (.) & 0.00 & (.) & 0.00 & $()$. \\
\hline $40-49$ & 0.26 & $(0.56)$ & 0.00 & $(0.01)$ & 0.25 & $(0.87)$ \\
\hline $50+$ & -0.49 & $(0.92)$ & -0.28 & $(0.93)$ & 0.55 & $(1.93)$ \\
\hline \multicolumn{7}{|l|}{ Education level: } \\
\hline No upper secondary & 0.35 & $(0.30)$ & -1.14 & $(1.62)$ & $-1.10^{*}$ & $(2.06)$ \\
\hline Vocational & 0.94 & $(1.39)$ & -0.33 & $(0.70)$ & -0.18 & $(0.39)$ \\
\hline Technical or grammar school & -0.12 & $(0.22)$ & $-0.68^{*}$ & $(2.45)$ & $-0.71^{* *}$ & $(2.65)$ \\
\hline Professional degree & 0.19 & $(0.35)$ & -0.13 & $(0.48)$ & -0.50 & $(1.64)$ \\
\hline University degree (ref.) & 0.00 & (.) & 0.00 & $()$. & 0.00 & (.) \\
\hline \multicolumn{7}{|l|}{ Household type: } \\
\hline One-person household (ref.) & 0.00 & (.) & 0.00 & (.) & 0.00 & (.) \\
\hline Two adults with children & 1.56 & $(1.42)$ & $1.94^{* *+}$ & $(3.78)$ & 0.30 & $(0.65)$ \\
\hline Two adults without children & 1.40 & $(1.12)$ & $1.63^{* *}$ & $(2.72)$ & -0.02 & $(0.04)$ \\
\hline Single-parent household & 0.00 & $()$. & 0.95 & $(1.49)$ & 0.24 & $(0.39)$ \\
\hline Multigenerational household & 1.84 & $(1.66)$ & $1.98^{*+\cdots}$ & $(3.72)$ & -0.18 & $(0.36)$ \\
\hline \multicolumn{7}{|l|}{ Work-related events: } \\
\hline Worked from home & -0.10 & $(0.20)$ & -0.34 & $(1.23)$ & $0.51^{*}$ & $(2.07)$ \\
\hline Was on furlough & & & 0.48 & $(1.89)$ & -0.08 & $(0.34)$ \\
\hline Work-family balance worsened & & & -0.00 & $(0.01)$ & $1.25^{* * *}$ & $(5.27)$ \\
\hline Had workload reduced & $-1.07^{*}$ & $(2.17)$ & -0.17 & $(0.73)$ & -0.25 & $(1.09)$ \\
\hline Had wage reduced & & & 0.14 & $(0.54)$ & 0.05 & $(0.18)$ \\
\hline \multicolumn{7}{|l|}{ Received wage subsidy: } \\
\hline No (ref.) & 0.00 & $()$. & 0.00 & $()$. & 0.00 & $()$. \\
\hline Yes & 0.35 & $(0.78)$ & 0.17 & $(0.59)$ & 0.16 & $(0.56)$ \\
\hline No response & -0.01 & $(0.03)$ & -0.13 & $(0.41)$ & 0.55 & $(1.86)$ \\
\hline & & & & & & \\
\hline $\begin{array}{l}\text { Constant } \\
\text { Observations }\end{array}$ & \multicolumn{2}{|c|}{622} & \multicolumn{2}{|c|}{659} & \multicolumn{2}{|c|}{659} \\
\hline Pseudo $R^{2}$ & \multicolumn{2}{|c|}{0.113} & \multicolumn{2}{|c|}{0.074} & \multicolumn{2}{|c|}{0.098} \\
\hline$B I C$ & \multicolumn{2}{|c|}{421.49} & \multicolumn{2}{|c|}{861.27} & \multicolumn{2}{|c|}{886.55} \\
\hline
\end{tabular}

Note: $z$ statistics in parentheses (absolute values), ${ }^{*} p<0.05,{ }^{* *} p<0.01,{ }^{* * *} p<0.001$ 


\title{
Svi u istom čamcu? Razlike u iskustvu zaposlenosti i rizicima tijekom prvog vala pandemije COVID-19 u Hrvatskoj
}

\author{
Teo Matković \\ Institut za društvena istraživanja u Zagrebu, Hrvatska \\ e-mail: teo.matkovic@idi.hr \\ Marko Lucić \\ Ministarstvo rada, mirovinskoga sustava, obitelji i socijalne politike, Zagreb, Hrvatska \\ e-mail:marko.lucic@mrosp.hr
}

\section{Sažetak}

Iskustvo rada u okolnostima prvog vala pandemije za one koji su ostali zaposleni bilo je podložno poremećajima za većinu zaposlenih. Prema rezultatima početnog vala panel anketnog istraživanja SOCRES projekta provedenog između 20. kolovoza i 2. listopada 2020. koji se u radu analiziraju, šest od sedam zaposlenih doživjelo je neku od promatranih promjena vezanih za rad uslijed pandemije (razdoblje bez rada, smanjeno radno opterećenje, obuhvaćenost potporama za očuvanje radnih mjesta, rad od kuće, teže spajanje radnih i obiteljskih obveza, značajno smanjena plaća). Zaposlene ispitanike kategorizirali smo u šest segmenata s obzirom na epidemiološke restrikcije i potpore s izravnim implikacijama po tržište rada. Ispitali smo razlike u pojavnosti disruptivnih događaja, posebno narušene ravnoteže poslovnog i privatnog života te pada plaće i prihoda kućanstva. Osim toga, ispitali smo i razlike u percepciji tegobnosti situacije u okolnostima pandemije, kontaktu s virusom i samoiskazu pogoršanog zdravlja. Uzeli smo u obzir sociodemografske karakteristike (razinu obrazovanja, tip i sastav kućanstva, dob i spol) te ulogu potpora za očuvanje radnih mjesta u objašnjenju varijacija. Među pojedinim segmentima radnika nije utvrđeno mnogo nejednakosti u pojavnosti disruptivnih događaja osim onih koji očito proizlaze iz mjera. Identificiran je negativan utjecaj disruptivnih događaja na prihode, percepciju tegobnosti situacije i samoprocjenu zdravlja. Pad plaće i prihoda kućanstva bili su najčešći za samozaposlene, a otežano usklađivanje radnih i obiteljskih obveza za zaposlene u obrazovanju i zdravstvu. Široka primjena potpora fiksnog iznosa bliskog minimalnoj plaći dosegla je i osokolila značajan broj radnika, ali nije uspjela kompenzirati financijske posljedice pandemije. Nalazi o utjecaju pandemije na ravnotežu poslovnog i privatnog života upućuju na potrebu učinkovitog organiziranja usluga obrazovanja i skrbi, otpornog na zatvaranje.

Ključne riječi: COVID-19, Hrvatska, zaposleni, nejednakosti na tržištu rada, promjene na radnom mjestu, prihodi, ravnoteža poslovnog i privatnog života, zdravlje. 